\title{
The Role of Vegetation on the Dynamics of Water and Fire in the Cerrado Ecosystems: Implications for Management and Conservation
}

\author{
Carlos A. Klink *(D), Margarete N. Sato, Giovanna G. Cordeiro (i) and Maria Inês M. Ramos \\ Department of Ecology, University of Brasilia (UnB), 70910-900 Brasília, Brazil; \\ nsatoecologia@gmail.com (M.N.S.); giogomes.2402@gmail.com (G.G.C.); nesita03@gmail.com (M.I.M.R.) \\ * Correspondence: carlosklink@gmail.com
}

Received: 3 November 2020; Accepted: 7 December 2020; Published: 18 December 2020

\begin{abstract}
The Cerrado is the richest savanna and is undergoing one of the planet's most rapid land transformations for pasture and agriculture; around $45 \%$ of the biome has been deforested. Agriculture is of strategic importance to Brazil, but it also modifies ecosystems and jeopardizes habitats and biodiversity. Well-managed agricultural lands can have a favorable impact on environmental conservation. In this paper, we reviewed our current knowledge about water ecology and fire management to show that an ecosystem services perspective can bring about a conciliation of agriculture production with conservation by supporting effective land use decision-making and the optimization of public policy. The landscape/watershed scale seems to be the most relevant for decision-making on how to achieve production and conservation results. This scale appears to be an appropriate level for engaging with stakeholders. Fire frequency and timing (season) combination are determinant of individuals' survivorship. The combination determines vegetation recovery, and it is important to maintain high biodiversity, especially for the herbaceous layer, but it is a limitation to woody vegetation recovery. A pragmatic and conciliatory land use agenda must be based on scientific knowledge and support innovative decision-making solutions for policy-makers and stakeholders, particularly farmers and donors.
\end{abstract}

Keywords: ecosystem services; land use and conservation; public policies

\section{Introduction}

In Brazil and abroad, the Cerrado biome is seen as one of the last major land frontiers of the world. In contrast, it also harbors high biodiversity, dynamic landscapes, and is critical to protecting water resources, as it hosts the headwaters of important Brazilian hydrographic basins which supply nearly all the nation's biomes.

It has become Brazil's largest source of soybeans and pastureland, and a significant producer of corn, cotton, and sugarcane. Land use decisions are driven by technological innovations, capital investments, knowledge, and policy interventions. The primary objective of Cerrado land use is to expand intensive agriculture to meet the demand for agricultural products in Brazil and internationally. Pastures cultivated with African grasses, cash crops and planted forests are the main types of land use that today cover $40 \%$ of the Cerrado; native vegetation still covers $56 \%$ of the biome [1,2].

The strong performance of the Brazilian economy during the 1960s and 1970s, associated with a national development policy aimed at integrating the "empty" spaces of the Cerrado and Amazon biomes into the Brazilian economy, created the business environment for investments. Policies aimed at expanding the agricultural output of the Cerrado included subsidies, developmental programs, and the use of new technologies [3-7]. 
From a revenue-generation perspective, the benefits of commercial agriculture in the Cerrado are a success: soybeans and soy products are among the largest of Brazil's export commodities, and it supports the largest cattle herd in the country. Even so, the development of modern agriculture in the region has exacerbated social inequality at a high environmental cost, leading to landscape fragmentation, loss of biodiversity, biological invasion, soil erosion, water pollution, land degradation, heavy use of chemicals, changes in fire regime, and alterations of carbon and water cycling. Transformation of the landscape continues, but a series of new policies and instruments are being implemented that may change the future direction of land use in the Cerrado.

Several environmental and economic conditions have favored these transformations. Although rainfall distribution throughout the year is uneven, the mean total annual rainfall is considered sufficient for crop production. Sunshine is year around and mild temperatures do not restrict photosynthesis. The Cerrado's level topography suits mechanization, and the savannas are cheaply and more easily cleared for farming or cattle ranching than tropical rainforest.

The Cerrado climate is mostly rainy and tropical with two well-defined seasons, the wet (rainy) season, which usually runs from October through May, and the dry season from April through September. The average rainfall in the central Cerrado is $1500 \mathrm{~mm}$ per year, but there is a large variability in precipitation that can range from $400 \mathrm{~mm}$ (in the transition areas with the Caatinga biome in the Northeast of Brazil) to $2400 \mathrm{~mm}$ of rain per year (in the transition areas towards the Amazon rainforest). It is common to have dry spells of up to 20 days without rain during the wet season (locally known as "veranicos"), usually between December and February [8]. At the peak of the dry season it is common to have long periods without any rain (August-September).

In this paper, we reviewed our current knowledge about water ecology and fire management to show that an ecosystem services perspective can bring about a conciliation of agriculture production with conservation by supporting effective land use decision-making and the optimization of public policy. Both the conservation of ecosystems and agriculture are of strategic importance to Brazil. We argue that the richness of Brazilian policies on land use can both provide well-managed agricultural lands and have a favorable impact on environmental conservation.

\section{Water in the Cerrado Biome}

Water is the most limiting resource for plant productivity in several terrestrial ecosystems. The seasonality in soil water availability is considered a key factor in determining ecosystem function and vegetation structure [9]. Plant and microbial physiological activity are highly dependent upon water availability, and therefore, so are ecosystem processes such as primary production and decomposition. In the Cerrado biome, ecosystem processes that are strongly responsive to soil moisture include vegetation phenology [10], grass biomass production, carbon assimilation rates [11,12] and soil respiration [13].

The central location of the Cerrado biome in the Brazilian territory, its high elevation, and its deep soils are critical to protecting water resources, as they support a wide network of rivers and aquifers that supply important hydrographic basins of Brazil (Figure 1). This abundance commonly raises debates regarding the role of Cerrado in providing water to other regions of Brazil, including more than $50 \%$ of the country's hydroelectric production [14], and in maintaining water quality, which is related to the conservation of riparian vegetation alongside rivers [15-20]. 


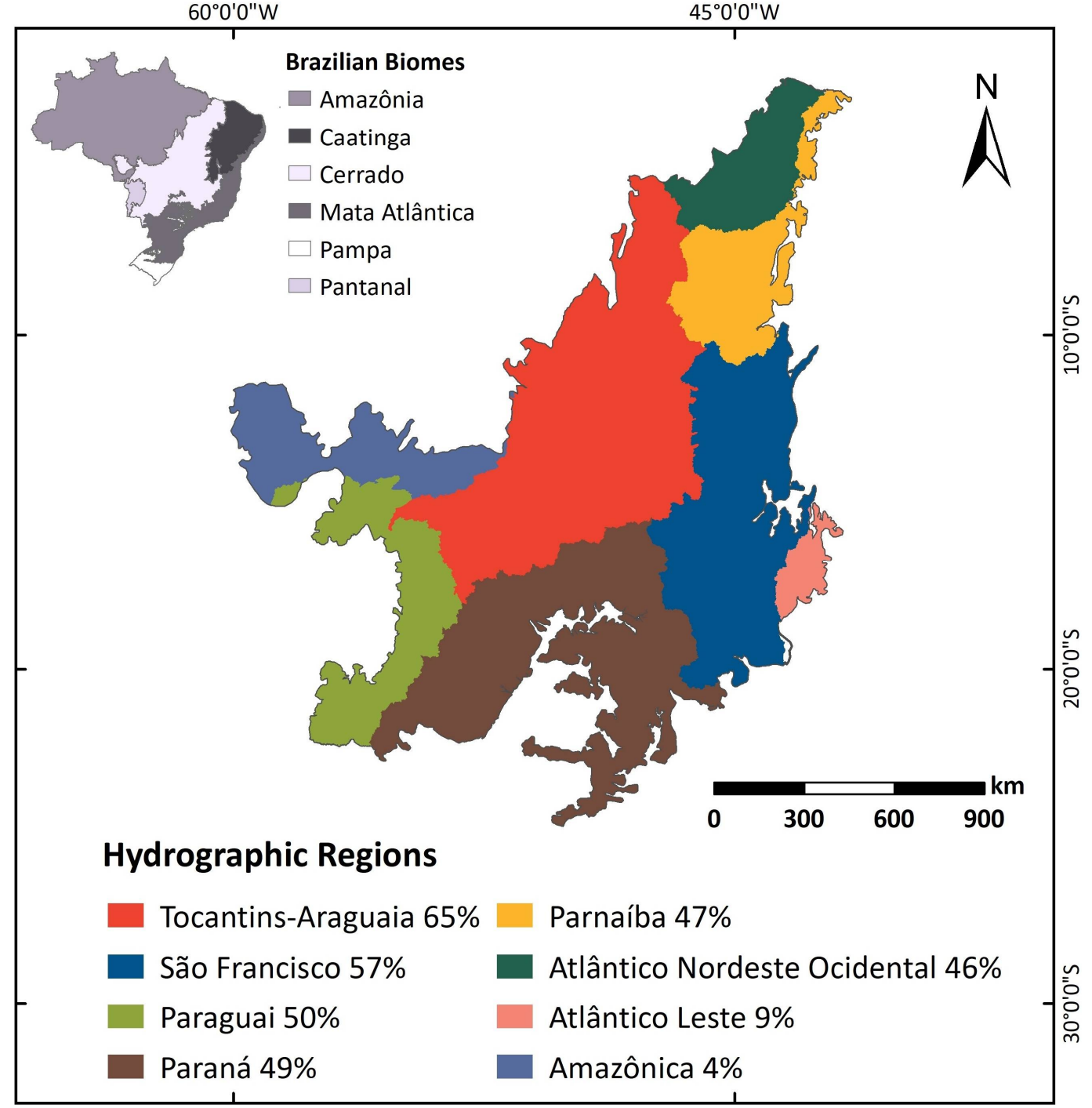

Figure 1. The Cerrado biome's contribution to the hydrographic regions in Brazil (modified from Sano et al. [21]). The numbers refer to the proportion of each hydrographic basin within the Cerrado biome.

It is well documented that the ecological heterogeneity in the Cerrado (Figure 2) results from the variation in climate (rainfall and temperature), geology, geomorphology, soil, and dominant vegetation type $[8,22,23]$. This ecological heterogeneity influences both the energy (input and output of energy flux) and the water balance (inputs and outputs of water through the vegetation and the soil), which depends on hydrological processes such as precipitation, evapotranspiration, water interception by vegetation, stem flow, water infiltration and percolation in the soil profile, soil surface runoff, and water absorption by roots. 


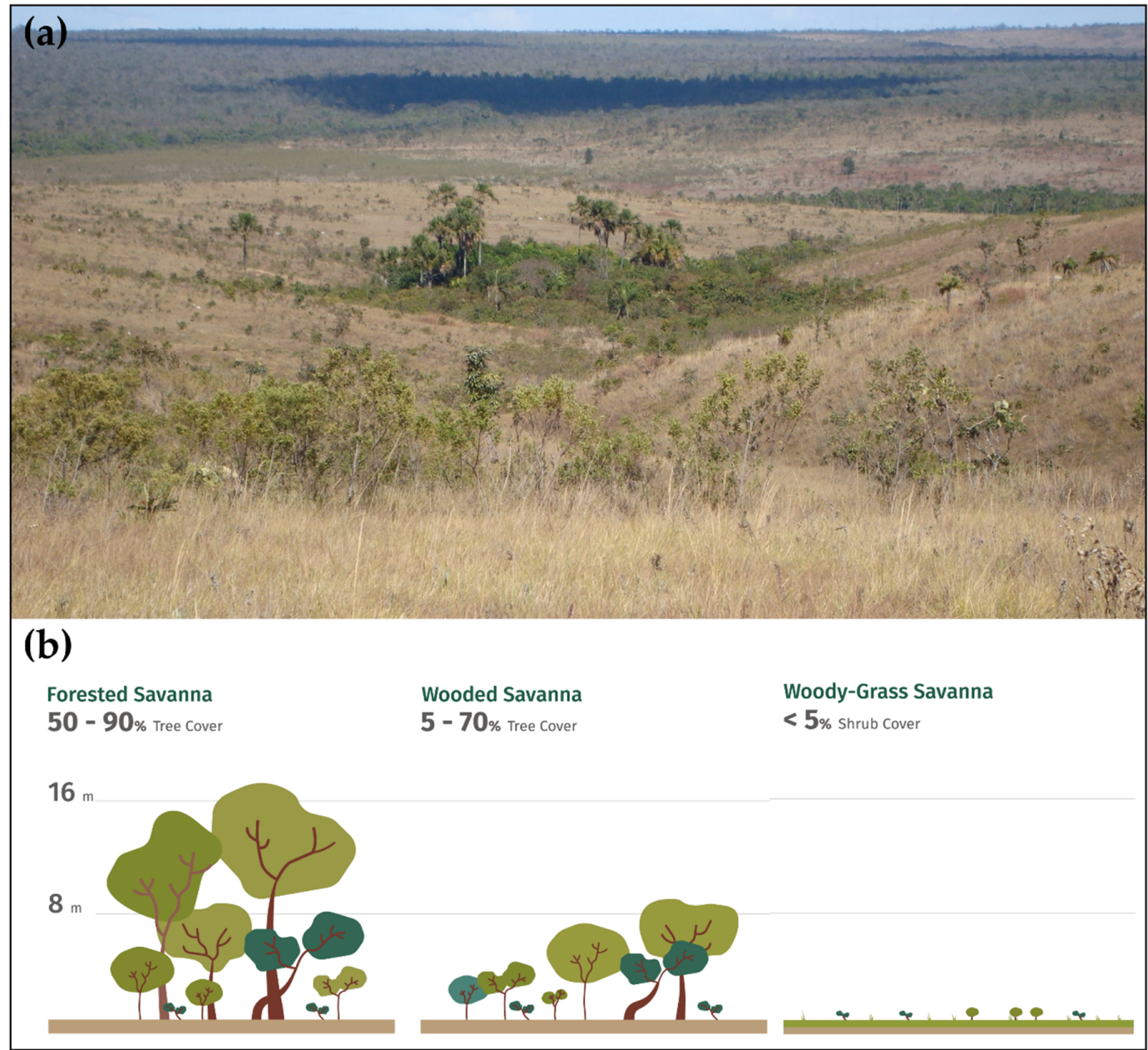

Figure 2. (a) The Cerrado's main feature is the coexistence of trees and shrubs on a matrix of herbs and grasses. Riparian forests follow the stream and river margins (Photo is courtesy from Reserva Ecológica do Roncador, RECOR/IBGE, Brasília, Brazil); (b) The high species richness (number of species) and vegetation structure (height and canopy cover) shows the ecological complexity of the Cerrado.

\subsection{Changes in Ecosystem Vegetation Cover Affect Hydrology and Precipitation}

For a long time, scientists and practitioners have been debating the effects of vegetation cover on rainfall and how this debate should inform policy making, especially in the tropics [24-33]. It is common to hear anecdotes from farmers that after the suppression of native savannas, "downstream water comes with force." However, deforestation usually affects hydrological processes, changing runoff characteristics, water yield, groundwater recharge, and soil infiltration capacity, as well as precipitation and evaporation rates [16,34-38].

Scientific evidence shows that increases in streamflow are typically short-lived and can ultimately degrade water quality and increase vulnerability to flooding [39]. These changes are especially worrying when the Cerrado's natural vegetation is replaced by pasture and croplands that are poorly managed. Therefore, establishing sustainable agricultural systems that prevent soil degradation can provide important environmental benefits in the Cerrado region, including reduced erosion rates, and increased nutrient uptake, water storage, carbon sequestration and biodiversity, among others [40-44].

The current debate revolves around whether forests are net users or producers of water. The "supply-side" thinkers argue that forests are net producers of waters and increase rainfall at regional scales. On the other hand, the "demand-side" thinkers argue that trees are users of water and that they decrease water availability for other users (farmers and city dwellers) at the catchment 
scale [45]. This debate on the role of forests in controlling water balance has been on for over a century. The issue of forest-rainfall feedback has gained prominence for the past 30 years due to concerns related to deforestation and climate change in the policy and scientific domains, and apparently the controversy is still not resolved [45-48].

In Brazil, this debate is heated by concerns about the significant rates of deforestation in the country. The deforestation of forests and savannas for the expansion of agroecosystems is the main driver of land cover changes in the Brazilian territory [49-61]. The conversion of natural ecosystems releases carbon to the atmosphere and affects land surface biophysical properties, including evapotranspiration, albedo (the reflectivity of the land surface), and the roughness of the vegetation, all of which influence local precipitation patterns [25]. The release of aerosols from burning forests and savannas can also affect the formation of clouds and precipitation [25,62]. All these changes have implications for agricultural production, which depends on temporal and spatial patterns of temperature and precipitation.

Climate and ecological modeling as well as field studies have shown some influence of the deforestation of tropical forests on the formation of clouds and rainfall. Modeling projections performed for the National Plan for Adaptation to Climate Change published predictions that the Cerrado might experience a reduction in precipitation of $35-45 \%$ by the end of the century, and that the regional temperature might increase by up to $5-5.5^{\circ} \mathrm{C}$ [63]. Costa and Pires [64] have concluded that Cerrado deforestation may increase the duration of the dry season from 5 to 6 months. They performed a modeling analysis for Cerrado's future scenarios, based on atmospheric and biophysical parameters, and related the effect of deforestation to rainfall and the duration of the dry season.

More recently, Cohn et al. [65] explored non-local warming within Brazil's Amazon and Cerrado biomes, using two datasets, one consisting of in-situ air temperature observations and a second consisting of remotely-sensed observations of land surface temperature. The study evaluated air temperature response to non-local forest loss occurring at distances from 1 to $60 \mathrm{~km}$ from the monitoring sites. The results showed substantial non-local warming, suggesting that historical evaluations underestimate or misattribute warming to local change, where non-local changes also influence the patterns of temperature increases.

Transforming native ecosystems into pasture and croplands has induced regional climate change in the past 40 years, due to reduced net surface radiation and evapotranspiration, and increased sensible heat flux and land surface temperature after deforestation [66]. The authors reported that the Xingu Indigenous Park is $3{ }^{\circ} \mathrm{C}$ cooler than the mosaic of agricultural lands and the fragmented forests that surround the park in the state of Mato Grosso. They also reported reduced rainfall and extended dry season in deforested areas in the state of Rondônia.

More specific analyses have predicted significant differences in productivity, carbon, and evapotranspiration rates when native Cerrado ecosystems are compared to the most important agroecosystems of the region, pasture, and croplands. Using "vegetation greenness indexes" and evapotranspiration indexes derived from remote sensing (MODIS) for the 2000-2012 period, Arantes et al. [67] categorized the effects of land cover and land use changes into primary productivity, carbon, and evaporative fluxes of these different ecosystems. The authors found that for the year 2002, the total amount of carbon biomass for the entire Cerrado region (in the wet season) was estimated as $28 \mathrm{Gt}$ of carbon, and evapotranspiration was $1336 \mathrm{Gt}$ of water. From this total, native ecosystems accounted for $15 \mathrm{Gt}$ of carbon and $760 \mathrm{Gt}$ of water, while pastures and croplands combined summed up to $12 \mathrm{Gt}$ of carbon and $576 \mathrm{Gt}$ of water. Simulating future land cover scenarios (for the year 2050), the authors reported that evapotranspiration from the remaining native Cerrado ecosystems (predicting current trends of deforestation) would be $394 \mathrm{Gt}$ less than in 2002.

Clearly, there are some scientific predictions for the possible effects of changes in vegetation cover and rainfall, but we still lack more definitive empirical evidence to fully understand and make policy-relevant predictions for the ecosystems-rainfall relationship. There is also a lack of evidence about the viability of the concept of ecosystem services for decision-making in the Cerrado, which is discussed below. 


\subsection{The Role of Water as an Important Ecosystem Service in the Cerrado}

A number of initiatives have been launched with the goal of mainstreaming the concept of ecosystem services in Brazil, for public policy, business [68], and public awareness [69]. All of these have been important for engaging academia, civil society, and the media, but they still lack the necessary traction to make ecosystem services a more operational concept for decision-making and investments in Brazil. The empirical, scientific, or policy-relevant literature on the importance of water as an ecosystem service in the Cerrado is scarce.

There has been an increase in technical and methodological ecosystem valuation studies in Brazil, but most were site-specific and did not evaluate the value of ecosystems at larger scales or the construction of an environmental services market, particularly related to rural development in Brazil [70]. More recently, the use of other economic instruments, such as water charges and payments for ecosystem services, started to be introduced. The National Water agency launched in 2011 the water producer program, to financially compensate farmers that invest in soil and water conservation [71,72].

This national program is one of the instruments of the national water policy and seeks to promote the sustainable use and conservation of water resources. It is targeted toward the watershed level and requires the participation of both public and private entities. The goal is to pay farmers who adequately manage their lands and forests, and therefore become providers of ecosystem services (through "payment for environmental services" schemes). Eligible interventions include the maintenance of watersheds, the protection of native vegetation, tree plantation, the protection of riparian forests, soil management and protection, no-till agriculture, the restoration of degraded pastures and agroforestry systems, among others.

The theme of ecosystem services in the Cerrado biome is still dominated by ecological and academic analysis. Watanabe and Ortega [73] made a simulation analysis to quantify how relevant water and carbon are as ecosystem services provided by the Cerrado. They simulated the impacts of changes in land cover for water and carbon biogeochemical processes. The land cover change history of the Taquarizinho watershed, located in the eastern state of Mato Grosso do Sul, was used as the baseline since the region has been converted into crops and pastures since the 1960s. The impacts on ecosystem services were estimated by creating a hydro-carbon model that used several parameters related to water and carbon dynamics (evapotranspiration, channel discharge, groundwater recharge, biomass, litter, and soil). The model allowed us to simulate such dynamics for different land uses for an entire river basin, and to ordinate the values of ecosystem services associated with each vegetation cover category.

When studying the relationship between the establishment and management of agroecosystems and the provision of ecosystem services in three Brazilian biomes (Atlantic Forest, Cerrado, and Caatinga), Turetta et al. [74] assessed the use of soil parameters as indicators to monitor changes in agroecosystems. They found that water infiltration, nutrient cycling, sediment retention, and carbon sequestration and accumulation are the soil functions most affected by the agroecosystems. The authors also indicated four Brazilian public policies that present opportunities for farmers to improve the provision of ecosystem services from the agricultural system, by encouraging sustainable soil management practices. These include the following: "Plano Setorial de Mitigação e de Adaptação às Mudanças Climáticas" (Plano ABC), the Sector Plan for Mitigation and Adaptation to Climate Change for low carbon in agriculture; "Programa de Aquisição de Alimentos" (PAA), the Food Acquisition Program; "Programa Produtor de Água" (PPA), the Water Producer Program; and "Programa Nacional de Alimentação Escolar" (PNAE), the National School Feeding Program.

A more recent trend has shown conservation and economic gains when farming is in compliance with the Brazilian forest law, the Forest Code $[75,76]$. This analysis was carried out to demonstrate the value of changing the focus of framing ecosystem services from a project-by-project approach to a landscape-level approach. It did so because the landscape-level approach allows for a better understanding of the environmental externalities of land use, and explicitly shows the options when it is necessary to balance economic development with the conservation of natural ecosystems. The case 
study evaluated a commercial sugarcane expansion in a watershed in the state of Minas Gerais. The analysis applied economic and biophysical models to quantify the benefits of the Forest Code under different compliance scenarios, either at the farm level or the landscape-watershed level. For both scenarios, the best planning for habitat protection and forest restoration was evaluated.

The authors found that compliance with the Forest Code imposes low costs on businesses and can generate significant benefits for conservation by supporting additional species, storing additional carbon, and improving surface water quality. Landscape level compliance was shown to reduce total business costs (that ranged between USD 19 million and up to USD 35 million) for the period of a 6-year sugarcane growing cycle, while supporting more species and more carbon. The analysis showed that it is possible to maximize net returns from sugarcane production at the landscape level, and at the same time meet the requirements of the Forest Code.

Mapping ecosystem services at the landscape level has also been shown to be useful. Researchers developed a comprehensive approach to map ecosystem services in the Cerrado based on a spatially explicit approach, called MapES [77]. The approach is based on the premise that knowledge can be applied into decision-making related to land use and to protect the capacity of ecosystems in providing environmental services. Knowledge about eight ecosystem services (erosion and runoff control, water supply and quality, soil quality, conservation of biodiversity, food production, and energy production) was structured to provide parameters that can be evaluated against the dominant land cover/land use within a landscape. Landscape biophysical properties are made spatially explicit on maps using information about soil types, slope, and distance to the river network. The method was then tested based on a reference map of potential natural vegetation and land uses for a meso-scale catchment (Sarandi, a $32.7 \mathrm{~km}^{2}$ catchment located at Brasília/Federal District).

Using these approach, users and practitioners can visualize changes from human intervention on the landscapes and assess potential impacts from land use and land cover changes on ecosystem services. The integrated assessment of ecosystem services allows users to analyze ranges of uncertainties (upper and lower thresholds) and the interrelated effects of different land uses. For instance, high values of uncertainty and wide ranges between different land uses were found for biodiversity conservation in the Sarandi catchment (uncertainty factor of 0.4; ecosystem service values between 60 and 100), which results from the uncertainty in measuring relevant criteria for this ecosystem service. Meanwhile, water supply carries less uncertainty and a high accuracy of measurements $(0.05 ; 59$ and 65$)$.

The study points out that the most important limitation of its use is the limited knowledge of the complex interaction of land use/land cover changes and ecosystem services in a landscape unit. However, the approach can be adapted to real case situations, and can be an important tool to support decision-making and integrate ecosystem services in landscape planning.

\section{Fire as an Ecological and Anthropological Factor in the Cerrado Biome}

Long before scientists described the use of "cleaning fires" in Brazil [78], naturalists such as Warming in 1778 described the use of fire during the dry season (now known as a controlled fire), whereby the main goal was to "clean" the land or to renew pasturelands [79]. The most likely primary reason for the use of fire is that it is a cheap and easy-to-use tool. Other human groups use fire for different goals, such as the indigenous people who use it to stimulate flower and fruit production and as a hunting technique, and traditional communities who use it to clean pasture and open new agricultural areas.

Nowadays, $8 \%$ of the Cerrado biome burns annually, which represents 17 Mha and occurs across all types of vegetation or phyto-physiognomies [80]. Cerrado's natural fires are caused by lightning, and mostly occur at the transition between the dry and the wet season (October to November), when lightning without rain occurs, or during dry spells ("veranicos") in the wet season. Human-made fires occur mainly during dry season (July to October). While some plants appear adapted to fire, others suffer irreversible damage if the frequency of the fire changes. Fire also leads to changes in the vegetation's structure (trees' height and density), and the recovery of the vegetation can take decades. 
No doubt fire plays a role in the native Cerrado by transforming the vegetation structure, species composition and dynamics [81-83], and is one of the most important determinant factors, especially when used to maintain the diversity of phyto-physiognomies and biodiversity, or used by humans as a management tool to open areas for agriculture and for keeping native pasture green at the end of the dry season.

Nonetheless, there is still no full comprehension about how fire affects the Cerrado vegetation or even what is the adequate fire regime (frequency, timing, and severity). So, there is a conflicting approach to policy-making regarding the use of fire, which ranges from full protection against the use of fire to the proposal to use fire as a management tool to reduce fuel biomass and avoid large late wildfires.

\subsection{Fire and Vegetation Formations}

The Cerrado biome can be described as composed of two major vegetation formations: savannas and forests. The characteristics used to differentiate savannas from forests include vegetation structure (trees height and density), the dominant life forms (trees, shrubs, herbs, grasses), and phenology (deciduous-when trees and shrubs shed leaves). Savannas are the dominant form in the Cerrado biome $(\sim 75 \%)$ and contain two vegetation strata, one layer with scattered shrubs and trees and another with grasses or graminoids that dominate the herbaceous layer; on the other hand, forests $(\sim 25 \%$ of the biome) are dominated by trees with a closed canopy of at least $70 \%$ in the rainy season but with no grass layer $[23,84]$. Because of these differences, savannas and forests show contrasting fire behavior and effects.

\subsection{Fire Behavior}

\subsubsection{Forest Formations}

There is little information of the effect of fire on forest phyto-physiognomies in the Cerrado. In general, the forest formations present a microclimate, near the surface of the soil, that is unfavorable to the propagation of surface fire, such as high humidity, lower temperature, and the absence of wind [85], as well as the presence of a litter layer or organic matter on the ground, but not a herbaceous layer.

The occurrence of natural fire in forest formations is rare; however, surface fires do occur and consume the litter deposited on the ground, causing death and/or top-kill (destruction of the above-ground structure of the plants) of some plants. The flame height is about $40 \mathrm{~cm}$, but does not reach the canopy of the vegetation [86-89]. Only $2.8 \%$ of the forest area burned annually is the result of surface fires [87]. Balch et al. [90] reported that surface fire in a forest is not trivial, as in their study it took four consecutive days, with the addition of kerosene and fuel biomass at some points, to perform a prescribed burning in the experimental areas in a forest in the transition zone within the Cerrado, even after more than two months without rainfall.

Most of the burning in forest formations occurs in previously deforested or altered areas [91-93]. In general, burning occurs where vegetation has been cut previously and then burned (slash and burn) or in partially deforested areas, when slashing the vegetation is not necessary [94]. Slash and burn is essential for the formation of pastures or agricultural lands in the Amazon [85].

\subsubsection{Savanna Formations}

Due to the structural characteristics of the savanna vegetation, that is, a continuous herbaceous layer with great variation in the density of woody plants that do not form a continuous canopy, and the seasonality in rainfall, the fires in savannas are usually surface fires. The fuel biomass, where fire propagates, is in the herbaceous layer, which is composed mainly of grasses or graminoids, leaves and stems (diameter smaller than $6 \mathrm{~mm}$ ). The fire is fast-fire spread rates between $0.2 \mathrm{~m} / \mathrm{s}$ and $0.5 \mathrm{~m} / \mathrm{s}$ are usual, but sometimes in very special environmental conditions they could reach a maximum value of 
$2.2 \mathrm{~m} / \mathrm{s}[95,96]$ and the mean flame height reaches $2.5 \mathrm{~m}$, sometimes scorching some crowns of arboreal individuals $[95,97-99]$.

\subsection{Cerrado Annually Burned Area}

The Brazilian Space Agency, INPE, has monitored changes in the Amazon forest cover since 1988. Starting in 2016, INPE also monitors changes in Cerrado cover. In Brazil, the total area burned annually is around $35 \mathrm{Mha}$, of which over half is in the Cerrado, or 17 Mha (Table 1). Rosan et al. [92] estimate $16 \mathrm{Mha} / \mathrm{yr}$ of Cerrado burned area from 2001 to 2015, where 52\% of the area presented no fire during the period, $35 \%$ with two fires, $10 \%$ with five fires and $3 \%$ more than five fires.

Table 1. Area burned annually in the Cerrado [80].

\begin{tabular}{ccc}
\hline Year & Burned Area (ha) & $\mathbf{( \% )}$ \\
\hline 2003 & $17,514,000$ & 8.6 \\
2004 & $19,868,400$ & 9.8 \\
2005 & $18,169,000$ & 8.9 \\
2006 & $11,810,900$ & 5.8 \\
2007 & $32,913,800$ & 16.2 \\
2008 & $13,945,800$ & 6.9 \\
2009 & $7,435,300$ & 3.7 \\
2010 & $30,482,500$ & 15.0 \\
2011 & $13,498,800$ & 6.6 \\
2012 & $24,745,100$ & 12.2 \\
2013 & $11,100,400$ & 5.5 \\
2014 & $17,075,600$ & 8.4 \\
2015 & $19,050,600$ & 9.4 \\
2016 & $15,114,200$ & 7.4 \\
2017 & $15,835,200$ & 7.8 \\
2018 & $8,537,400$ & 4.2 \\
\hline Mean & $17,318,562$ & 8.5 \\
\hline
\end{tabular}

We used data for the 2010 fires not associated with deforestation, whereby of the total area burned, $94.2 \%$ was savanna and $5.8 \%$ forest, and this calculation considered the park savanna, woody grass savanna, wooded savanna, forested savanna, wooded steppe savanna, forested steppe savanna and fluvial and/or lacustric (riparian forest) which influenced vegetation as savanna formations. Of the burned savanna, $76 \%$ was wooded savanna and park savanna. Of the burned forests, $98 \%$ were seasonal forest (Appendix II of the Third National Communication of Brazil to the United Nations Framework Convention on Climate Change-MCTI 2016 [100]).

Natural fires are ignited by lightning (mainly during the transition from dry to wet season). There is no lightning during the dry season (May to October), therefore dry season fires are due to the increased role of humans since indigenous occupation. Anthropic fires are generated especially by farmers for renewing pastures, opening new areas for agriculture, or even controlling pests. Rainy season fires, on the other hand, may have either natural or anthropic origins [101-103].

Recently, some experts have considered that fire exclusion from the Cerrado would be by itself a "disturbing agent" of ecosystems. Therefore, there has been proposed the implementation of Integrated Adaptive Fire Management (MIF) in protected areas with the goals of reducing fuel biomass (and consequently the occurrence of severe fires), controlling invasive grasses, or allowing for the use of fire by traditional or indigenous communities [104-108].

\subsection{Fire Frequency in Phyto-Physiognomies}

Experts have reported the frequency of occurrence of fires in protected areas in order to understand fire return. In the Cerrado's conservation units, Alvarado et al. [109] observed that for $80 \%$ of burnings in the period from 1984 to 2014, the interval between burnings was less than 5 years. Pereira et al. [110] 
reported for savanna's open physiognomies, such as park savanna and wooded savanna, that the burning frequency is every 3 years, and together these studies represent $\sim 84 \%$ of the area burned annually. Denser phyto-physiognomies, such as forest savanna, present a fire interval of 5 years and represent about $4 \%$ of the area burned annually. Vegetation associated with drainage, such as "vereda" palm forest with graminoids, present intermediate values of fire return (3 to 4 years).

\subsection{Vegetation and Species Adaptation to Fire}

European naturalists exploring the Brazilian landscapes in the early and mid-19th century (for instance Langsdorff and Warming) already described the recovery of Cerrado vegetation after fire and the association between edaphic and climate aspects to explain fire frequency, the plant's architecture, and vegetation density $[79,111,112]$. In the early 1960 s a series of studies conducted by botanists associated the existence of xylopodium and other underground organs as features that allowed the recovery of plants after fire. Today, it is known that there is a large diversity in the underground systems in the Cerrado plants from which originate the belowground buds (so called "bud banks") that allow re-sprouting after fire [113].

For a long time, these belowground features, and thick barks of shrubs and trees, have been considered to have evolved as adaptations to drought and/or nutrient-poor Cerrado soils. More recently, it has been reported that they should be considered as fire adaptations since these attributes coincided with the expansion of tropical savannas grasses [114-116].

Even though Cerrado plants may have these traits, fire can still affect species distribution and the composition of species in the ecosystem. Some aerial structures can be consumed during fire, diminishing plant biomass, and damaging or even killing the plant. As such, those adaptative traits should be useful for protecting or allowing the persistence of species, but that depends on fire regimes, especially how frequently burning occurs. It is known that increased fire frequency can diminish re-sprouting capacity, even of adapted species, and those species with no such traits (not adapted) may suffer increased mortality $[117,118]$.

\subsection{The Importance of Long-Term Ecological Studies}

The Cerrado contains one of the richest floras in the world-more than 12,000 plant species have been described, of which $80 \%$ are herbs and shrubs found particularly in open savannas [119]. At least $40 \%$ of this flora is considered endemic to the Cerrado [120]. New plant species endemic to the Cerrado have been recently described in the literature, such as Poaceae [121], Apocynaceae [122], Convolvulaceae [123], Lentibulariaceae [124], Orchidaceae [125], and Leguminosae [126]. In addition to endemism, Ratter et al. [127] indicate that the distribution of most woody species is rare, that is, 682 species of the 914 inventoried occur in 50 or less studied sites, with 334 species found in a single site.

Even though fire in the Cerrado has been known for a long time, it is only recently that researchers started to study its effects on the vegetation and ecosystems. Up to 1990, there were no fire experiments, and reports were primarily about accidental fires on previously established research plots or short-term observations on species composition or flowering. From long-term studies of fire on Cerrado vegetation conducted in Brasilia, it has been possible to monitor the effects of more frequent fire events in the same site, and what modifications this brings to the structure and functions of ecosystems, especially the role of more frequent anthropogenic fires set during dry season.

\subsection{How Fire Affect These Two Savanna's Strata: The Dynamic of Recovery after Fire}

\subsubsection{Herbaceous Layer Vegetation}

Fire directly affects herbaceous layer species, since some plants are totally consumed by fire, such as grasses and other graminoids (mostly of monocots as Cyperaceae, Xyridaceae, Iridaceae), while some are only partially consumed by fire (eucots). It is possible to identify four patterns of re-sprouting 
after fire [128], based on when maximum biomass is reached: (1) at the beginning of wet season; (2) in the middle of the wet season; (3) in the second half of the wet season; and (4) end of dry season.

Several studies accounted for the number of herbaceous layer species flowering after fire. For instance, Coutinho [129] recorded massive flowering a few days or weeks after fire (Figure 3). Silva and Nogueira [130] recorded 96 species flowering one month after a fire and 147 species one year after the fire. Munhoz and Felfili [131] recorded 106 species flowering 3 months after a fire and 128 species eight months after it.

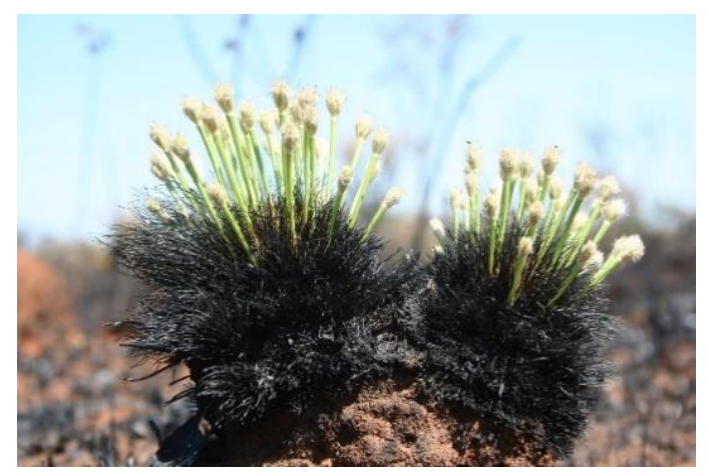

(a)

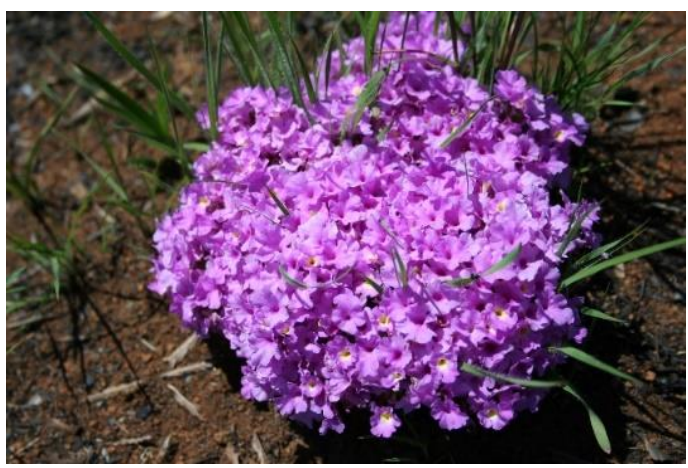

(b)

Figure 3. (a) Bulbostylis paradoxa flowering starts one day after fire, (b) Lantana montevidensis blooming one month after fire.

Regardless of the pattern presented by the species, one year after a fire at least half of fuel biomass (mainly grass and graminoids) is recovered, depending on the fire frequency, the timing when the fire is set, the precipitation, and the type of soil. In the central region of the Cerrado biome, at least $70 \%$ of fuel biomass is recovered until the middle of the following rainy season. Dead biomass represents $65 \%$ of the total, and this percentage is quite important information, for it suggests the possibility of sustaining a new fire event later on if there is enough fuel biomass [132].

Knowing the dynamics of the fuel biomass allows us to understand if or when Cerrado can be burned, and infer that open savannas physiognomies, such as the wooded savanna, the woody grass savanna, the park savanna, and the fluvial and/or lacustric influenced vegetation, can potentially be burned anytime one year after a previous fire.

\subsubsection{Woody Layer}

In general, the woody layer is not consumed by fire, but high temperatures can damage parts of trees, and their recovery depends on the frequency of fire and fire season. Fire adaptations, such as thick bark, that allow resistance to high temperatures during fire, or the regrowth ability after a fire that increases the persistence of the species, are important traits, since high temperatures can directly affect plants, especially small plants and trunks, or indirectly affect them through hot air (convection air), resulting in damage to branches, leaves, flowers, and fruits. The main types of damage and resprouting (Figure 4) are described by Sato et al. [133]:

1. Light damage-partial damage with aerial resprout (epigeal), that is, new leaves and branches on the main trunk;

2. Moderate damage or top-kill—partial damage with basal and/or subterranean resprout (hypogeal) and death of main trunk;

3. Severe damage- - total damage with no resprout after at least two growth seasons, that is, plant mortality;

4. Top-kill + Severe damage $=$ stems destroyed.

Thus, the size of the plant is important; not only plant height that may allow plants to escape the flame zone, but also trunk diameter, because there is a positive correlation between diameter 
and bark thickness. Tree seedlings suffer severe damage (50\%) or top-kill [134]. Most small woody plants, such as subshrubs and shrubs (less than $5 \mathrm{~cm}$ in basal diameter), could suffer from moderate to severe damage. It has been reported for instance that for a park savanna, $22.5 \%$ of woody individuals (diameters equal or larger than $2 \mathrm{~cm}$ ) died after a prescribed fire [135]. More than $60 \%$ of alive plants presented light damage after the first fire; after the third fire, this was reduced to $42 \%$. The number of sprouting plants also diminished, decreasing the capacity of individuals to survive. Fire frequency therefore is an important indicator of savanna vegetation becoming more open.

Damage to woody plants ( $5 \mathrm{~cm}$ or larger in diameter) submitted to biennial prescribed fires in park savanna and wooded savanna was reported by several studies $[133,136,137]$. Severe damage, after a first fire, was less than 13\%, ranging from 5\% for park savanna burned in August to $13 \%$ for wooded savanna burned in September. The severity of the damage increases after five biennial fires, reaching up to $48 \%$ (late burn on park savanna). The timing of the fire appears to be an important factor that leads to changes in vegetation structure, whereby late dry season fires can cause more destroyed stems $(75 \%$ on wooded savanna) than early fires ( $41 \%$ on park savanna). Even with these high percentages of stems destroyed, some plants reach the minimum diameter size $(5 \mathrm{~cm}$ or more-new individuals). Counting the plants that reach the minimum diameter size along with plants that suffer only light damage results in the maintenance of at least $65 \%$ of trees for early fires and only $28 \%$ for late fires. So, in addition to fire frequency, the timing of fire onset (the fire season) is indeed an important factor that affects arboreal individuals, changing its architecture, population size and reproductive factors [138-140].

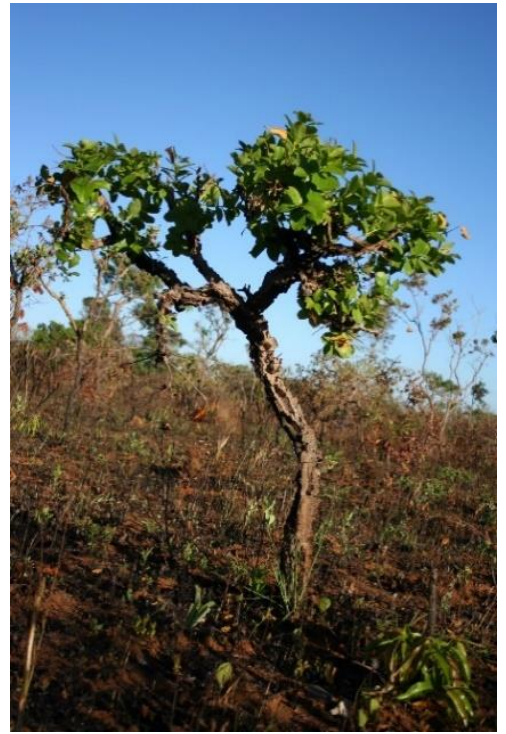

(a)

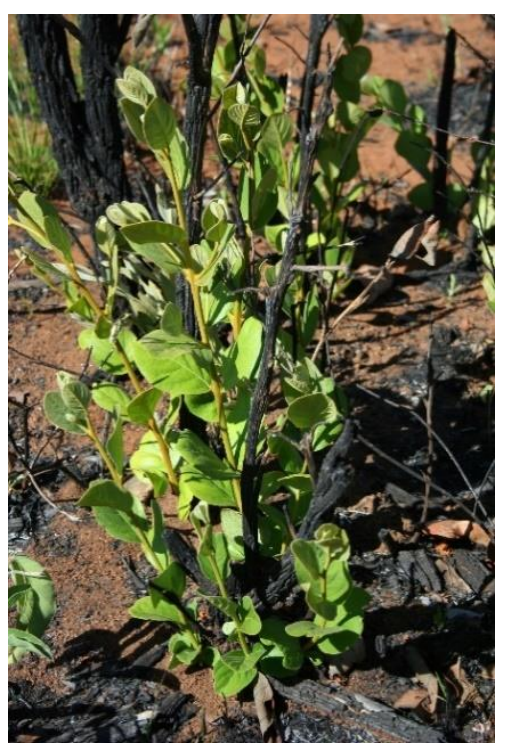

(b)

Figure 4. (a) Symplocos rhamnifolia with aerial resprouting (light damage), (b) Styrax ferrugineus with top-kill (moderate damage) after a fire in Cerrado.

\subsection{Changes in Vegetation Structure}

Fire frequency and fire season, then, are important factors in changing the structure of the vegetation. Late fires reduce basal area and tree cover by destroying the stems and favoring the herbaceous layer occupation of the ecosystem, especially of grasses [137,141]. In contrast, fire exclusion may increase woody individuals and fire-sensitive species, as shown for forested savanna and park savanna structures, so the vegetation becomes more closed without fire [141]. Nevertheless, despite those increments, there is no evidence that fire changes one phyto-physiognomy into another entirely, since edaphic limitations play an important role in determining Cerrado physiognomies [142]. Only when the vegetation before fires was already a more closed physiognomy can the increment 
of woody plants and tree species, after a long time of fire suppression (over 20 years), change phyto-physiognomies [143-145].

\subsection{Ecosystem Functions: Water and Carbon Exchange between Ecosystems and the Atmosphere}

Changes in vegetation structure and composition alter the functioning of ecosystems $[11,12,146]$. For a park savanna, after three mid-biennial fires, there was an increase in the evaporation from 0.5 to $1.0 \mathrm{~mm}$ of water per day, and a reduced use of deep water in the soil (below $1 \mathrm{~m}$ ) [146]. In an unburned wooded savanna, there was a slightly larger demand for water than frequently burned savanna; in this case, the burned savanna uptakes water mainly from the top $2 \mathrm{~m}$ [147].

Carbon fluxes are also related to changes in vegetation structure and composition. In an unburned park savanna, the carbon accumulation was $2.9 \mathrm{MgC} / \mathrm{ha}$, while for a burned park savanna it was $4.6 \mathrm{MgC} / \mathrm{ha}$ [12]; for wooded savanna, the carbon accumulation was between $1.5 \mathrm{MgC} / \mathrm{ha}$ and $2.6 \mathrm{MgC} / \mathrm{ha}$ [148-150]. In open savannas, where grasses with the $\mathrm{C}_{4}$ photosynthesis type are the major component of the total biomass, the carbon accumulation is as high as that reported for burned park savanna.

\subsection{Fire and Conservation}

Fires are natural disturbance events that maintain savannas as mosaic vegetation from grassland to woody savanna. This depends on a combination of the fire regime, especially fire frequency and season, the soil (type, depth, nutrients content), and precipitation. Some experts called this the "vegetation dynamic alternative stable state" or "savanna stable state theory" [151-153]. Though this concept has value for expanding our scientific knowledge on Cerrado ecology, it is still unclear how it can become a more operational concept for Cerrado conservation or fire management.

Regardless of whether it is necessary or not, Cerrado's fire is always an issue or a threat for decision-makers, mainly because burning releases carbon into the atmosphere, and kills trees and animals. Some recent research discussed whether or not fire should be used and how to change policies from zero tolerance to integrated fire management [154-157].

In the Brazilian policy-making regime, the conservation of biodiversity and ecosystems can be achieved by two major categories-by the public and the private sectors. Public conservation interests are established by the designation of protected areas (conservation units in the Brazilian jargon) that can be local, state, or national in scope. They are of different sizes and goals, but usually are established for the conservation of landscapes, biodiversity, and ecosystem services. Other public lands, such as indigenous reserves and quilombolas communities (traditional slave descendants), also support conservation, but have different goals such as keeping integrity, the perennialism of their culture, and the untouchability of traditional populations.

Conservation in private lands, on the other hand, is either mandatory as per the Forest Code by which farmers have to comply with setting aside lands for "legal reserves" and "permanent protected areas", or voluntarily designated set asides, by which farmers or land owners can create private reserves, usually in perpetuity following the normative of the national systems of protected areas (private reserves for nature preservation, or RPPN in the Brazilian jargon).

Usually for both public and private conservation, a major concern is the restoration of degraded lands and how to manage fire as a tool to ensure biodiversity, landscape, and ecosystem services. For the Cerrado, fire is already explicitly considered in the policy-making framework, as shown below:

- Within the Forest Code, the Ministry of the Environment submitted a bill in 2018 to regulate the use and control of fire in rural areas, and the definition of governance and roles for the Federal and state agencies. The bill includes the implementation of integrated fire management approaches, which have been used already in some protected areas, indigenous lands, and private lands throughout the Cerrado. The bill is under analysis by the Brazilian National Congress.

- Within the Action Plan for Prevention and Controlling of Deforestation and Fires (PPCerrado, one of the instruments of the National Policy on Climate Change), the prevention and control 
of forest fires is one of its main objectives. Already, the Cerrado Monitoring Programs (Prodes and DETER/Cerrado-http://terrabrasilis.dpi.inpe.br/) provide information on forest fire risks and the contribution from deforestation and fires in the Cerrado to the national greenhouse gas emissions inventories.

\section{Agriculture Development and Changes in Land Use in the Cerrado}

Though human presence in Central Brazil dates back more than 9000 years, it is only in recent times that human occupation has occurred. Since colonial times, Brazilian society has thought of central Brazil as a region to be conquered and transformed. The first permanent settlements were established by the Portuguese in the early 18th century and were associated with gold mining [5]. After the Paraguay War (1864-1870), Cerrado occupation was promoted by Brazilian authorities, who were concerned that the Cerrado's exceptionally low population density meant the country would be unable to defend and maintain its border.

The first major economic boom in the Cerrado came during the period 1920-1930, when coffee growing and processing industries were booming in the state of São Paulo, which then became the major market for Cerrado cattle. From 1930 through 1945, the Federal government actively promoted the colonization of southern Goiás, providing land, subsidies, and technical assistance, and encouraging farmers to settle on and clear relatively fertile forested lands $[3,158]$. This had important implications for the Cerrado's land use. Until the late 1950s, the contribution of the Cerrado to Brazil's agricultural output was very low, contributing less than $10 \%$ of the national total. Dramatic changes started in the late 1960s, and by the 1970s and 1980s, the Cerrado became Brazil's major producer and exporter of important cash crops and beef.

The major obstacle to the occupation and development of the Cerrado has been its distance from the major Brazilian urban areas along the coast and the lack of a transport system. Construction of the first railway was initiated in 1905, and after 1946 roads replaced railways as the main means to link the Brazilian regions. The construction of Brasilia in the 1960s at the core of the Cerrado made possible the linking of the new capital by highways to the main Brazilian cities, and brought the modern occupation of the Cerrado [5].

Today, new links to connect the Cerrado to external markets are planned or underway. Most noteworthy among these are the paving of the BR-163 highway in central Amazonia to carry soybeans to the international port of Santarém in the Amazon river and the "Pacific" highway that connects the Cerrado to the Pacific Ocean through the state of Acre, Bolivia, and Peru. The construction of railways is again becoming fashionable. One of the most notable projects is Ferro Norte, a railway that is going to link the Cerrado to Brazil's largest port (Santos), in order to carry soybeans to external markets.

One of the main instruments used by the Brazilian government to promote agricultural development during the 1960-1980s was subsidized credit, particularly low-interest farm loans $[5,6]$. Subsidies were also granted for fertilizers, pesticides, and machinery. As these incentives were offered at fixed rates, lower than the high inflation rates of the time, they all represented further subsidies to producers. As a result, credit to the rural sector between 1969 and 1979 was 199\% for agriculture and 164\% for livestock production [5]. After 1979, credit flows slowed, especially long-term investment credit.

Loans were not evenly distributed among crop types. Over $75 \%$ of production loans were concentrated in six crops: soybeans, rice, coffee, wheat, maize, and sugarcane. Soybeans alone received $20 \%$ of the credit available to Brazilian farmers [5]. Since loans were allocated based on the area planted, it encouraged extensive and inefficient agriculture [159]. Cerrado farmers received $70 \%$ more credit than Amazon and northeast farmers, where the small producers of food crops are concentrated. This readily available credit increased the demand for land in the Cerrado and drove up land prices $[5,6]$. 
In addition to the incentives and subsidies policies, other strategies have been used to develop and occupy Cerrado land, most importantly regional developmental programs, the deployment of new technologies, and minimum prices policies.

The Program for the Development of the Cerrado (POLOCENTRO) of 1975, a public program, settled farmers in places with good farming potential, improved secondary roads and electricity, and developed agriculture research and technology [5]. The program had a major impact on Cerrado agriculture. Big farms (larger than 1000 hectares in size) accounted for $39 \%$ of all projects and received more than $60 \%$ of the credit. The program's original goal of giving preference to foodstuffs was never realized, and, instead, the program induced the expansion of commercial agriculture (cattle ranching and soybeans).

POLOCENTRO was closed in 1985, but already in the late 1979s, the Brazil-Japan Cooperative Program for the Development of the Cerrado (PRODECER), a private program, was created. PRODECER selected experienced farmers from the south and southeast of Brazil to be settled in the Cerrado for soy production. It was financed by loans from both the Brazilian and the Japanese governments, but contrary to the POLOCENTRO, loans were granted at real (not fixed) interest rates. PRODECER ended in 2001.

The creation in 1973 of EMBRAPA (the Brazilian Agricultural Research Corporation, a public company) and its several decentralized research centers allowed for the development of appropriate technologies to enable farmers to deal with Cerrado's acidic soils with low nutrient availability, and the tropical climate (rain seasonality, temperature, humidity, evapotranspiration rate, wind), as well as genetic improvement, has also promoted agricultural expansion. The technologies included the use of modern machinery in agricultural operations, application of phosphate fertilizer and lime to correct for soil nutrient deficiency and acidity, Rhizobium-based nitrogen fixation, the development of crop varieties, the use of herbicides and pesticides, and modern machinery [3,160].

The price support policy in Brazil, which guarantees a minimum price for agricultural products, has been in effect since the 1930s. In the 1980s, farm credit lines were restricted and reduced or eliminated. Consequently, production costs increased substantially in the Cerrado. The government then started to purchase large amounts of Cerrado products, particularly soybeans, rice, and corn [6]. The net result was the expansion of commercial farming in areas that could not have supported profitable production without the subsidies and, consequently, the deforestation of new land.

\section{Evolution of Cerrado's Policy Framework}

In the past, Brazil's land use policies were often formulated with little attention to their implications for land degradation, social conflict, and biodiversity conservation. However, over the past 15 years, Brazil has built a robust set of environmental regulations at the national and subnational levels [72,161], yet few of these policies are specific to the Cerrado's conservation and sustainable use. Priority and attention have been given to the Amazon forest, not the Cerrado. Therefore, the Cerrado is underrepresented in the National System of Conservation Units (SNUC); 8.7\% of the Cerrado's surface area is under legal conservation compared to $26.1 \%$ of the Amazon's [162].

The Brazilian Forest Code demands farmers to conserve 20-35\% of their properties for sustainable use and conservation purposes. The implementation of the Forest Code, which applies to both the Amazon and the Cerrado, has emerged as the most important institutional driver of land use in the biome (a combination of agriculture production and ecosystem conservation).

However, the Federal and the state-level governments are still struggling to implement the law, especially due to (i) low institutional capacity at the regional and local scale, (ii) persistent problems with land conflicts and land tenure regularization, (iii) a lack of incentives to farmers to fully engage them in the Forest Code implementation, and (iv) a recurring change in the regulatory framework related to Forest Code implementation terms.

Despite these factors, the deforestation rates in the Cerrado have decreased from around 30,000 $\mathrm{km}^{2}$ for the year 2001 to $6900 \mathrm{~km}^{2}$ on average for the last three years [163,164]. For the methodological and 
regional differences in deforestation rates, see Alencar et al. [61]. There is an increasing pressure from civil society and the private sector to implement more sustainable practices in the biome. Introducing the next generation of monitoring systems and improving the transparency of property and land use data will be key for building on this new momentum.

Land use and ecosystems are key for achieving the Sustainable Development Goals (SDGs) and the Paris Climate Change Agreement. These goals set an ambitious roadmap to inspire government planning and the mobilization of stakeholders that recognize the three dimensions of sustainable development in a comprehensive set of goals and targets; they allow the movement from theory to practice. There is no question the COVID-19 pandemic is also exerting an extraordinary pressure for more sustainable agriculture production and green investments in Brazil $[165,166]$.

Public investments are driving the demand for sustainability in the Cerrado, and there is a substantial portfolio of budgetary resources, national and international funds, and cooperation projects that are ready to finance sustainable land use in the biome. Farmers' access to these resources and their transactional costs are still a barrier, but incentivizing a transition to deforestation-free supply chains, pasture and forest restoration, and territorial consolidation in the Cerrado, are anticipated outcomes.

The private sector has voiced major concerns regarding the still relatively high levels of deforestation related to the expansion of agriculture and pasture. Eighteen initiatives seeking more sustainable production have been introduced in Brazil recently, sponsored by foundations, NGOs, traders, companies, and banks to promote the economic benefits of land use that help conserve ecosystems. The implementation of these actions still poses challenges: initiatives focus mainly on supply chains (particularly of soy and beef) that aim at "zero net deforestation" in the Amazon and the Cerrado, and there is almost no support for complementary actions or the avoidance of fragmented (or antagonistic) initiatives. Another key challenge is the noticeable absence of a clear and extensive engagement with farmers.

The new political agenda of the Federal government for agriculture and the environment, and the recent free trade agreement between Mercosur and the EU, may have important impacts on land use in the Cerrado. Promoting the better coordination of policies that aim simultaneously at ecosystem conservation, sustainable land use, and climate change mitigation is still a challenge in the Cerrado. In Tables S1 and S2 in the Supplementary Materials, we describe the most relevant policy instruments that might drive more sustainable land use in the Cerrado in the near future, as well as current funding mechanisms for advancing initiatives in the Cerrado.

\section{Building a Better Future for Sustainable Agricultural Production in the Cerrado}

There is an unprecedent opportunity to develop sustainable solutions for the Cerrado by bringing the main stakeholders together-the business sector, foundations, public policy makers, researchers, rural farmers, and civil society. The goal is to understand the trade-offs between ongoing land use transformation and the consequences to ecosystems in the Cerrado, to identify opportunities for land use decisions that maintain ecosystem functions without constraining food and bioenergy production, and to build a new narrative for ecosystem services for the Cerrado.

\subsection{Why the Cerrado Needs a New Road Map for Production}

Brazil's abundant lands in the Cerrado and the ingenuity and hard work of its farmers and producers have transformed the nation into a global agricultural powerhouse. Today, Brazil ranks as one of the world's leading agribusiness producers and exporters [4]. From 1977 to 2019, agricultural production skyrocketed from $8 \mathrm{Mt}$ to $130 \mathrm{Mt}$. Yet to maintain Brazil's global standing to meet the world's food demand, reduce hunger, and rehabilitate land, a new and ambitious roadmap for production in the Cerrado is needed; one that is rooted also in environmental sustainability.

Brazil has already proven that agricultural development can continue to grow even when deforestation is curbed, if technology, policies, and science is correctly deployed. The next step is 
to demonstrate how ecosystem protection can add economic value to agricultural production in the Cerrado.

Our current scientific knowledge shows that Cerrado's natural vegetation can play a fundamental role in conserving water and protecting the healthy functioning of ecosystems. This is why Brazil's private and business sectors need to join forces with national and international academics, civil societies, nonprofit organizations, and governments to improve practices and supply the rising demand for agriculture products that have been developed sustainably.

Fortunately, Brazil is ideally positioned for creating a more sustainable business model (see MAPA 2020 [167]). The Cerrado's business and policy environment has many strengths that already bring agribusinesses and conservationists together [168,169], including:

- A highly competitive agribusiness industry;

- A vigorous commercial pulp, paper and timber industry;

- The ability to increase productivity in the region significantly through improved technology;

- An innovative and growing economic restoration industry;

- An advanced research and development (R\&D) capacity;

- Consolidated civil society organizations;

- The opportunity to cultivate already cleared areas and lands for agricultural production;

- A strong policy framework to promote ecosystem services and conservation in private lands;

- Evidence that shows the increased enforcement of deforestation does not undermine agricultural productivity or economic growth;

- Proven scientific and technical capacity to monitor ecosystems and deforestation.

This new collaboration between agribusiness and ecosystem conservation, if fully developed in the Cerrado, will create a transformative new business model for Brazil and the world. Formulating a new land use agenda will require buy-ins from both the agricultural and environmental constituencies, and must be based on solid science. If successful, Brazil has the potential to double its agricultural productivity while protecting its natural resources [161]. The new business model would establish Brazil as an example for the world and a global leader in agricultural growth and ecosystem protection.

\subsection{Ensuring the Potential of the Biome}

We propose to develop a pragmatic agenda for the Cerrado together with the agribusiness and conservation constituencies. The Cerrado has already seen many concrete examples of agribusinesses and conservationists working together successfully.

- Many farmers are seeking to achieve higher agriculture productivity while also seeking compliance with environmental regulations.

- Think-tanks, NGOs, academics and traders are building strategies for zero-deforestation in the mid-term.

- Financial flows and the mobilization of private investments have increased for green investments.

- New technologies and artificial intelligence are being deployed for better planning of the farming landscape.

- Farmer awareness regarding the environmental risks associated with agricultural production has increased.

In addition, much of Brazil's 180 Mha of pastureland is degraded with low productivity, and therefore represents a major opportunity for agriculture, bioenergy, and beef production to expand into this pastureland without further deforestation [170]. In several locations, low productivity pastureland is already being replaced by more intensive techniques and knowledge. Examples such as that described by Assunção et al. [171] for Mato Grosso do Sul underscore the potential to achieve the dual goals of improved productivity and reduced deforestation in the Cerrado. 


\section{Conclusions: Toward a Stronger Future in the Cerrado}

The insufficient scientific knowledge on ecosystem services must not justify inaction. Our knowledge would be of benefit if studies sought to find synergies between changes in land use/land cover and how they affect natural ecosystems and agroecosystems. To be policy relevant, knowledge from ecosystem services must clearly specify the spatial and temporal scales from which the best results are achieved. Assessments of ecosystem services must perform quantitative predictions and specify the implications for the existing policy options.

Knowledge about ecosystem services must provide evidence that benefits stakeholders. A key for protecting the Cerrado biome is to understand how the existing policy framework (especially compliance with the Forest Code, which demands huge investments in how best to design the landscape) can support decision-making by farmers about where to conserve the natural vegetation as required by the law.

A pragmatic and conciliatory land use agenda must be based on scientific knowledge and must support innovative decision-making solutions for policy-makers and stakeholders. To make scientific knowledge policy-relevant, it must be combined with stakeholders' and institutions' engagement, particularly farmers and donors. Farmers will ultimately have to decide on the "design" of landscapes in the Cerrado. Donors should support this goal through the creation and dissemination of relevant ecosystem services knowledge and by working with others (e.g., the finance sector; the public sector) to stimulate the creation of incentives for farmers to make the best use of ecosystem services.

To move forward with an agribusiness landscape where the importance of ecosystems and ecosystem services are fully integrated, it will be crucial to facilitate participation among the region's different stakeholders and organize where they fit into the new business model.

Three primary strategies must be used to build the road map that will lead to the new business plan for the Cerrado:

1. Create an active, solution-focused dialogue among farmers and organizational stakeholders in the Cerrado. Engaging farmers will help ensure that the new solutions for improved business practices can be leveraged and scaled up. Farmers and producers must be at the table in the development of the agribusiness-ecosystem business model so that they may benefit fully from the new actions taken under the model.

2. Develop, field test, and implement new business intelligence and tools that help farmers to manage or reduce agribusiness risk from degraded ecosystems. The development of critically needed business tools can be achieved by studying new farming practices and interviewing farmers, examining how state-of-the-art cleantechs and agtechs are operating, identifying and mobilizing new financial mechanisms and capital, and learning from new public-private approaches. The development of ecosystem indicators, environmental monitoring, economics studies, and the development of tailor-made solutions with farmers about how best to implement the Forest Code, must come in tandem as a component of this business intelligence.

3. Formalize partnerships wherever possible that serve the development of the new agribusiness-ecosystem business model. Throughout the Cerrado, numerous organizations and funders are seeking to advance agribusiness-ecosystem ideas like these, but they often lack farmer input and coordination at the regional level.

The "design" of landscapes in the Cerrado depends on each farmer or producer's decisions. The landscape/watershed scale seems to be the most relevant for decision-making on how to achieve production and conservation results in the Cerrado, and therefore the most promising for analytical work. The landscape/watershed scale also appears to be an appropriate level for engaging with stakeholders because at this scale, the knowledge about ecosystem services would most probably match stakeholders' demands related to the benefits accrued by ecosystem services.

Given the status of the current debate on the role of fire in policy making, it is expected that scientists, park rangers, and policy-makers have been pursuing an agenda for the use of fire as a management 
tool to guarantee the maintenance of biodiversity, the integrity of landscapes, and ecosystem services. We must bear in mind, however, that there are two important conditionalities for the use of fire as a management tool:

- Fire frequency is a major threshold. Vegetation recovery is highly dependent on fire frequency and maintains the Cerrado's high biodiversity, especially for the herbaceous layer, but it is a limitation to woody vegetation recovery;

- When combined with fire frequency, the season when fire occurs (timing) is a determinant of herbs, shrubs and trees survivorship, despite the fact that some species have useful traits (such as bud banks, underground systems and thick barks) for protection against fire that may allow for the increased survivorship of species.

Supplementary Materials: The following are available online at http://www.mdpi.com/2223-7747/9/12/1803/s1, Table S1: Brazil's policy instruments in ecosystem conservation, sustainable land use, and climate change mitigation for the Cerrado; Table S2: Funds and financing opportunities for the Cerrado.

Author Contributions: Conceptualization, C.A.K., M.N.S., G.G.C. and M.I.M.R.; methodology, C.A.K., M.N.S., G.G.C. and M.I.M.R.; formal analysis, C.A.K., M.N.S., G.G.C. and M.I.M.R.; investigation, C.A.K., M.N.S., G.G.C. and M.I.M.R.; resources, C.A.K.; data curation, M.N.S. and G.G.C.; writing-original draft preparation, C.A.K., M.N.S., G.G.C. and M.I.M.R.; writing-review and editing, C.A.K., M.N.S., and G.G.C.; visualization, M.N.S. and G.G.C.; supervision, C.A.K. and M.N.S.; project administration, C.A.K.; funding acquisition, C.A.K. All authors have read and agreed to the published version of the manuscript.

Funding: This research was funded by the project "Cerrado ecosystem service knowledge Centre", funded by CIFF Children's Investment Fund Foundation (grant R-1603-01190).

Acknowledgments: Administrative and technical support were provided by the Dept. of Ecology, University of Brasilia, and by the Climate Policy Initiative (CPI-Rio). We particularly acknowledge the support of Natalie Hoover and Carolina Marques of CPI.

Conflicts of Interest: The authors declare no conflict of interest. The funders had no role in the design of the study; in the collection, analyses, or interpretation of data; in the writing of the manuscript, or in the decision to publish the results.

\section{References}

1. Souza, C.M.; Shimbo, J.Z.; Rosa, M.R.; Parente, L.L.; Alencar, A.A.; Rudorff, B.F.T.; Hasenack, H.; Matsumoto, M.; Ferreira, L.G.; Souza-Filho, P.W.M.; et al. Reconstructing three decades of land use and land cover changes in brazilian biomes with landsat archive and earth engine. Remote Sens. 2020, 12, 2735. [CrossRef]

2. De Mattos Scaramuzza, C.A.; Sano, E.E.; Adami, M.; Bolfe, E.L.; Coutinho, A.C.; César, J.; Mora, D.; Eduardo, L.; Maurano, P.; Narvaes, S.; et al. Land-use and land-cover mapping of the brazilian Cerrado based mainly on LANDSAT-8 satellite images. Rev. Bras. Cartogr. 2017, 69, 1041-1051.

3. Klink, C.A. Policy Intervention in the Cerrado Savannas of Brazil: Changes in Land Use and Effects on Conservation. In Ecology and Conservation of the Maned Wolf: Multidisciplinary Perspectives; Press Cross: Boca Raton, FL, USA, 2014; pp. 293-308.

4. Klein, H.S.; Luna, F.V. Feeding the World: Brazil's Transformation into a Modern Agricultural Economy; Cambridge University Press: Cambridge, UK, 2019.

5. Klink, C.A.; Moreira, A.G. Past and Current Human Occupation and Land Use. In The Cerrados of Brazil; Press, CU: New York, NY, USA, 2002; pp. 69-88.

6. Mueller, B.; Mueller, C. The political economy of the Brazilian model of agricultural development: Institutions versus sectoral policy. Q. Rev. Econ. Financ. 2016, 62, 12-20. [CrossRef]

7. The Economist. Brazilian agriculture. The Miracle of the Cerrado: Brazil Has Revolutionised Its Own Farms. Can It Do the Same for Others? Available online: https://www.economist.com/node/16886442/print (accessed on 26 August 2010).

8. Silva, J.F.; Fariñas, M.R.; Felfili, J.M.; Klink, C.A. Spatial heterogeneity, land use and conservation in the cerrado region of Brazil. J. Biogeogr. 2006, 33, 536-548. [CrossRef]

9. Sarmiento, G. The Ecology of Neotropical Savannas; Harvard University Press: Cambridge, UK, 1984; ISBN 0-674-22460-4. 
10. Lenza, E.; Klink, C.A. Comportamento fenológico de espécies lenhosas em um cerrado sentido restrito de Brasília, DF. Rev. Bras. Bot. 2006, 29, 627-638. [CrossRef]

11. Miranda, A.C.; Miranda, H.S.; Lloyd, J.; Grace, J.; Francey, R.J.; Mcintyre, J.A.; Meir, P.; Riggan, P.; Lockwood, R.; Brass, J. Fluxes of carbon, water and energy over Brazilian cerrado: An analysis using eddy covariance and stable isotopes. Plantcell Environ. 1997, 20, 315-328. [CrossRef]

12. Santos, A.J.B.; Silva, G.T.D.A.; Miranda, H.S.; Miranda, A.C.; Lloyd, J. Effects of fire on surface carbon, energy and water vapour fluxes over campo sujo savanna in central Brazil. Funct. Ecol. 2003, 17, 711-719. [CrossRef]

13. Davidson, E.A.; Artaxo, P. Globally significant changes in biological processes of the Amazon Basin: Results of the large-scale Biosphere-Atmosphere Experiment. Glob. Chang. Biol. 2004, 10, 519-529. [CrossRef]

14. Lima, J.E.F.W.; da Silva, E.M.; Oliveira-Filho, E.C.; de Martins, E.S.; Reatto, A.; Bufon, V.B. The relevance of the Cerrado's water resources to the Brazilian development. Proc. Xiv World Water Congr. 2011, 8, 1-11.

15. Castro, D.M.P.; Carvalho, D.R.; Pompeu, P.D.S.; Moreira, M.Z.; Nardoto, G.B.; Callisto, M. Land use influences niche size and the assimilation of resources by benthic macroinvertebrates in tropical headwater streams. PLoS ONE 2016, 11, e0150527. [CrossRef]

16. Hunke, P.; Roller, R.; Zeilhofer, P.; Schröder, B.; Mueller, E.N. Soil changes under different land-uses in the Cerrado of Mato Grosso, Brazil. Geoderma Reg. 2015, 4, 31-43. [CrossRef]

17. Hunke, P.; Mueller, E.N.; Schröder, B.; Zeilhofer, P. The Brazilian Cerrado: Assessment of water and soil degradation in catchments under intensive agricultural use. Ecohydrology 2015, 8, 1154-1180. [CrossRef]

18. Valera, C.A.; Pissarra, T.C.T.; Filho, M.V.M.; do Valle Júnior, R.F.; Oliveira, C.F.; Moura, J.P.; Fernandes, L.F.S.; Pacheco, F.A.L. The buffer capacity of riparian vegetation to control water quality in anthropogenic catchments from a legally protected area: A critical view over the Brazilian new forest code. Water 2019, 11, 549. [CrossRef]

19. Parron, L.M.; Bustamante, M.M.C.; Markewitz, D. Fluxes of nitrogen and phosphorus in a gallery forest in the Cerrado of central Brazil. Biogeochemistry 2011, 105, 89-104. [CrossRef]

20. Cordeiro, G.G.; Vasconcelos, V.; Salemi, L.F.; Nardoto, G.B. Factors affecting the effectiveness of riparian buffers in retaining sediment: An isotopic approach. Environ. Monit. Assess. 2020, 735. [CrossRef] [PubMed]

21. Sano, E.E.; Rosa, R.; Brito, J.L.S.; Ferreira, L.G. Land cover mapping of the tropical savanna region in Brazil. Environ. Monit. Assess. 2010, 166, 113-124. [CrossRef] [PubMed]

22. Sano, E.E.; Rodrigues, A.A.; Martins, E.S.; Bettiol, G.M.; Bustamante, M.M.C.; Bezerra, A.S.; Couto, A.F.; Vasconcelos, V.; Schüler, J.; Bolfe, E.L. Cerrado ecoregions: A spatial framework to assess and prioritize Brazilian savanna environmental diversity for conservation. J. Environ. Manag. 2019, 232, 818-828. [CrossRef]

23. Ribeiro, J.F.; Walter, B.M.T. Fitofisionomias do bioma Cerrado. In Cerrado: Ambiente e Flora; Embrapa Cerrados: Planaltina/DF, Brazil, 2008; pp. 89-166. ISBN 85-7075-008-0.

24. Defries, R.S.; Foley, J.A.; Asner, G.P. Balancing human needs and ecosystem function. Front. Ecol. Environ. 2009, 2, 249-257. [CrossRef]

25. Foley, J.A.; Asner, G.P.; Costa, M.H.; Coe, M.T.; DeFries, R.; Gibbs, H.K.; Howard, E.A.; Olson, S.; Patz, J.; Ramankutty, N.; et al. Amazonia revealed: Forest degradation and loss of ecosystem goods and services in the Amazon Basin. Front. Ecol. Environ. 2007, 5, 25-32. [CrossRef]

26. Seymour, F.; Busch, J. Why Forests? Why Now? The Science, Economics, and Politics of Tropical Forests and Climate Change; Center for Global Development: Washington, DC, USA, 2016.

27. West, P.C.; Narisma, G.T.; Barford, C.C.; Kucharik, C.J.; Foley, J.A. An alternative approach for quantifying climate regulation by ecosystems. Front. Ecol. Environ. 2011, 9, 126-133. [CrossRef]

28. Anderegg, W.R.L.; Trugman, A.T.; Bowling, D.R.; Salvucci, G.; Tuttle, S.E. Plant functional traits and climate influence drought intensification and land-atmosphere feedbacks. Proc. Natl. Acad. Sci. USA 2019, 116, 14071-14076. [CrossRef] [PubMed]

29. Gimeno, L.; Dominguez, F.; Nieto, R.; Trigo, R.; Drumond, A.; Reason, C.J.C.; Taschetto, A.S.; Ramos, A.M.; Kumar, R.; Marengo, J. Major Mechanisms of Atmospheric Moisture Transport and Their Role in Extreme Precipitation Events. Annu. Rev. Environ. Resour. 2016, 41, 117-141. [CrossRef]

30. Jimenez, J.C.; Takahashi, K. Editorial: Tropical Climate Variability and Change: Impacts in the Amazon. Front. Earth Sci. 2019, 7, 1-2. [CrossRef]

31. Levine, N.M.; Zhang, K.; Longo, M.; Baccini, A.; Phillips, O.L.; Lewis, S.L.; Alvarez-Dávila, E.; De Andrade, A.C.S.; Brienen, R.J.W.; Erwin, T.L.; et al. Ecosystem heterogeneity determines the ecological resilience of the Amazon to climate change. Proc. Natl. Acad. Sci. USA 2016, 113, 793-797. [CrossRef] 
32. Marengo, J.A.; Souza, C.M.; Thonicke, K.; Burton, C.; Halladay, K.; Betts, R.A.; Alves, L.M.; Soares, W.R. Changes in Climate and Land Use Over the Amazon Region: Current and Future Variability and Trends. Front. Earth Sci. 2018, 6, 1-21. [CrossRef]

33. Spracklen, D.V.; Baker, J.C.A.; Garcia-Carreras, L.; Marsham, J.H. The effects of tropical vegetation on rainfall. Annu. Rev. Environ. Resour. 2018, 43, 193-218. [CrossRef]

34. Anache, J.A.A.; Wendland, E.; Rosalem, L.M.P.; Youlton, C.; Oliveira, P.T.S. Hydrological trade-offs due to different land covers and land uses in the Brazilian Cerrado. Hydrol. Earth Syst. Sci. 2019, 23, 1263-1279. [CrossRef]

35. Dias, L.C.P.; Macedo, M.N.; Costa, M.H.; Coe, M.T.; Neill, C. Effects of land cover change on evapotranspiration and streamflow of small catchments in the Upper Xingu River Basin, Central Brazil. J. Hydrol. Reg. Stud. 2015, 4, 108-122. [CrossRef]

36. Dionizio, E.A.; Costa, M.H. Influence of land use and land cover on hydraulic and physical soil properties at the cerrado agricultural frontier. Agriculture 2019, 9, 24. [CrossRef]

37. Nóbrega, R.L.B.; Guzha, A.C.; Torres, G.N.; Kovacs, K.; Lamparter, G.; Amorim, R.S.S.; Couto, E.; Gerold, G. Effects of conversion of native cerrado vegetation to pasture on soil hydro-physical properties, evapotranspiration and streamflow on the Amazonian agricultural frontier. PLoS ONE 2017, 12, e0179414. [CrossRef]

38. Spera, S.A.; Galford, G.L.; Coe, M.T.; Macedo, M.N.; Mustard, J.F. Land-use change affects water recycling in Brazil's last agricultural frontier. Glob. Chang. Biol. 2016, 22, 3405-3413. [CrossRef] [PubMed]

39. National Research Council. Hydrologic Effects of a Changing Forest Landscape; The National Academies Press: Washington, DC, USA, 2008; ISBN 0309121094.

40. Batlle-Bayer, L.; Batjes, N.H.; Bindraban, P.S. Changes in organic carbon stocks upon land use conversion in the Brazilian Cerrado: A review. Agric. Ecosyst. Environ. 2010, 137, 47-58. [CrossRef]

41. Carvalho, J.L.N.; Raucci, G.S.; Frazão, L.A.; Cerri, C.E.P.; Bernoux, M.; Cerri, C.C. Crop-pasture rotation: A strategy to reduce soil greenhouse gas emissions in the Brazilian Cerrado. Agric. Ecosyst. Environ. 2014, 183, 167-175. [CrossRef]

42. Galdino, S.; Sano, E.E.; Andrade, R.G.; Grego, C.R.; Nogueira, S.F.; Bragantini, C.; Flosi, A.H.G. Large-scale Modeling of Soil Erosion with RUSLE for Conservationist Planning of Degraded Cultivated Brazilian Pastures. L. Degrad. Dev. 2016, 27, 773-784. [CrossRef]

43. Da Silva, J.E.; Resck, D.V.S.; Corazza, E.J.; Vivaldi, L. Carbon storage in clayey Oxisol cultivated pastures in the "cerrado" region, Brazil. Agric. Ecosyst. Environ. 2004, 103, 357-363. [CrossRef]

44. Lopes, A.S.; Guimarães Guilherme, L.R. A Career Perspective on Soil Management in the Cerrado Region of Brazil; Elsevier Inc.: Amsterdam, The Netherlands, 2016; Volume 137, ISBN 9780128046920.

45. Bennett, B.M.; Barton, G.A. The enduring link between forest cover and rainfall: A historical perspective on science and policy discussions. For. Ecosyst. 2018, 5. [CrossRef]

46. Ellison, D.; Morris, C.E.; Locatelli, B.; Sheil, D.; Cohen, J.; Murdiyarso, D.; Gutierrez, V.; van Noordwijk, M.; Creed, I.F.; Pokorny, J.; et al. Trees, forests and water: Cool insights for a hot world. Glob. Environ. Chang. 2017, 43, 51-61. [CrossRef]

47. Honda, E.A.; Durigan, G. A restauração de ecossistemas e a produção de água. Hoehnea 2017, 44, $315-327$. [CrossRef]

48. van der Ent, R.J.; Coenders-Gerrits, A.M.J.; Nikoli, R.; Savenije, H.H.G. The importance of proper hydrology in the forest cover-water yield debate: Commentary on Ellison et al. (2012) Global Change Biology, 18, 806-820. Glob. Chang. Biol. 2012, 18, 2677-2680. [CrossRef]

49. Garcia, A.S.; Ballester, M.V.R. Land cover and land use changes in a Brazilian Cerrado landscape: Drivers, processes, and patterns. J. Land Use Sci. 2016, 11, 538-559. [CrossRef]

50. Assunção, J.; Gandour, C.; Rocha, R.; Rocha, R. The Effect of Rural Credit on Deforestation: Evidence from the Brazilian Amazon. Econ. J. 2020, 130, 290-330. [CrossRef]

51. Freitas, F.L.M.; Sparovek, G.; Berndes, G.; Persson, U.M.; Englund, O.; Barretto, A.; Mörtberg, U. Potential increase of legal deforestation in Brazilian Amazon after Forest Act revision. Nat. Sustain. 2018, 1, 665-670. [CrossRef]

52. West, T.A.P.; Börner, J.; Fearnside, P.M. Climatic Benefits From the 2006-2017 Avoided Deforestation in Amazonian Brazil. Front. For. Glob. Chang. 2019, 2. [CrossRef] 
53. Simmons, C.S.; Famolare, L.; Macedo, M.N.; Walker, R.T.; Coe, M.T.; Scheffers, B.; Arima, E.; Munoz-Carpena, R.; Valle, D.; Fraisse, C.; et al. Science in support of Amazonian conservation in the 21st century: The case of Brazil. Biotropica 2018, 50, 850-858. [CrossRef]

54. Garcia, A.S.; Vívian, V.M.; Rizzo, R.; West, P.; Gerber, J.S.; Engstrom, P.M.; Maria, M.V. Assessing land use/cover dynamics and exploring drivers in the Amazon's arc of deforestation through a hierarchical, multi-scale and multi-temporal classification approach. Remote Sens. Appl. Soc. Environ. 2019, 15, 100233. [CrossRef]

55. Rizzo, R.; Garcia, A.S.; Vilela, V.M.d.F.N.; Ballester, M.V.R.; Neill, C.; Victoria, D.C.; da Rocha, H.R.; Coe, M.T. Land use changes in Southeastern Amazon and trends in rainfall and water yield of the Xingu River during 1976-2015. Clim. Chang. 2020. [CrossRef]

56. Garrett, R.D.; Koh, I.; Lambin, E.F.; le Polain de Waroux, Y.; Kastens, J.H.; Brown, J.C. Intensification in agriculture-forest frontiers: Land use responses to development and conservation policies in Brazil. Glob. Environ. Chang. 2018, 53, 233-243. [CrossRef]

57. Joly, C.A.; Scarano, F.R.; Bustamante, M.; Gadda, T.M.C.; Metzger, J.P.W.; Seixas, C.S.; Ometto, J.P.H.B.; Pires, A.P.F.; Boesing, A.L.; Sousa, F.D.R.; et al. Brazilian assessment on biodiversity and ecosystem services: Summary for policy makers. Biota Neotrop. 2019, 19. [CrossRef]

58. Rajão, R.; Soares-Filho, B.; Nunes, F.; Börner, J.; Machado, L.; Assis, D.; Oliveira, A.; Pinto, L.; Ribeiro, V.; Rausch, L.; et al. The rotten apples of Brazil's agribusiness. Science 2020, 369, 246-248. [CrossRef]

59. Stabile, M.C.C.; Guimarães, A.L.; Silva, D.S.; Ribeiro, V.; Macedo, M.N.; Coe, M.T.; Pinto, E.; Moutinho, P.; Alencar, A. Solving Brazil's land use puzzle: Increasing production and slowing Amazon deforestation. Land Use Policy 2020, 91, 104362. [CrossRef]

60. Thaler, G.M.; Viana, C.; Toni, F. From frontier governance to governance frontier: The political geography of Brazil's Amazon transition. World Dev. 2019, 114, 59-72. [CrossRef]

61. Alencar, A.; Shimbo, J.Z.; Lenti, F.; Marques, C.B.; Zimbres, B.; Rosa, M.; Arruda, V.; Castro, I.; Ribeiro, J.P.F.M.; Varela, V.; et al. Mapping three decades of changes in the brazilian savanna native vegetation using landsat data processed in the google earth engine platform. Remote Sens. 2020, 12, 924. [CrossRef]

62. Davidson, E.A.; De Araüjo, A.C.; Artaxo, P.; Balch, J.K.; Brown, I.F.; Mercedes, M.M.; Coe, M.T.; Defries, R.S.; Keller, M.; Longo, M.; et al. The Amazon basin in transition. Nature 2012, 481, 321-328. [CrossRef] [PubMed]

63. Brasil. Ministério do Meio Ambiente. Plano Nacional de Adaptação à Mudança do Clima: Sumário Executivo; Ministério do Meio Ambiente (MMA): Brasília/DF, Brazil, 2016; p. 12.

64. Costa, M.H.; Pires, G.F. Effects of Amazon and Central Brazil deforestation scenarios on the duration of the dry season in the arc of deforestation. Int. J. Climatol. 2010, 30, 1970-1979. [CrossRef]

65. Cohn, A.S.; Bhattarai, N.; Campolo, J.; Crompton, O.; Dralle, D.; Duncan, J.; Thompson, S. Forest loss in Brazil increases maximum temperatures within $50 \mathrm{~km}$. Environ. Res. Lett. 2019, 14, 84047. [CrossRef]

66. Coe, M.T.; Brando, P.M.; Deegan, L.A.; Macedo, M.N.; Neill, C.; Silvério, D.V. The Forests of the Amazon and Cerrado Moderate Regional Climate and Are the Key to the Future. Trop. Conserv. Sci. 2017, 10. [CrossRef]

67. Arantes, A.E.; Ferreira, L.G.; Coe, M.T. The seasonal carbon and water balances of the Cerrado environment of Brazil: Past, present, and future influences of land cover and land use. Isprs J. Photogramm. Remote Sens. 2016, 117, 66-78. [CrossRef]

68. TEEB (The Economics of Ecosystems and Biodiversity). TEEB para o Setor de Negócios Brasileiro-Relatório Final; Conservação Internacional: Brasília/DF, Brazil, 2014.

69. Declaração do Capital Natural; GVCES: São Paulo, Brazil, 2018; p. 22.

70. Roma, J.C.; Junior, N.L.S.; Mation, L.F.; Paulsen, S.S.; Vasconcellos, P.G. A Economia de Ecossistemas e da Biodiversidade do Brasil (TEEB-Brasil): Análise de Lacunas; Ipea-Institute of Applied Economic Research: Rio de Janeiro, Brazil, 2013.

71. Agência Nacional de Águas (ANA) Nota informativa-Programa Produtor de Água. Available online: https://www.ana.gov.br/todos-os-documentos-do-portal/documentos-sip/produtor-de-agua/documentosrelacionados/1-nota-informativa-programa-produtor-de-agua.pdf (accessed on 30 June 2020).

72. OECD. OECD Environmental Performance Reviews: Brazil 2015. Oecd Publ. Paris 2015, 264. [CrossRef]

73. Watanabe, M.D.B.; Ortega, E. Dynamic emergy accounting of water and carbon ecosystem services: A model to simulate the impacts of land-use change. Ecol. Modell. 2014, 271, 113-131. [CrossRef] 
74. Turetta, A.P.D.; Tonucci, R.; de Mattos, L.M.; Amaro, G.; de Balieiro, F.C.; Prado, R.B.; de Souza, H.A.; de Oliveira, A.P. An approach to assess the potential of agroecosystems in providing environmental services. Pesqui. Agropecu. Bras. 2016, 51, 1051-1060. [CrossRef]

75. Kennedy, C.M.; Miteva, D.A.; Baumgarten, L.; Hawthorne, P.L.; Sochi, K.; Polasky, S.; Oakleaf, J.R.; Uhlhorn, E.M.; Kiesecker, J. Bigger is better: Improved nature conservation and economic returns from landscape-level mitigation. Sci. Adv. 2016, 2. [CrossRef] [PubMed]

76. Kennedy, C.M.; Hawthorne, P.L.; Miteva, D.A.; Baumgarten, L.; Sochi, K.; Matsumoto, M.; Evans, J.S.; Polasky, S.; Hamel, P.; Vieira, E.M.; et al. Optimizing land use decision-making to sustain Brazilian agricultural profits, biodiversity and ecosystem services. Biol. Conserv. 2016, 204, 221-230. [CrossRef]

77. Lima, J.E.F.W.; de Aquino, F.G.; Chaves, T.A.; Lorz, C. Development of a spatially explicit approach for mapping ecosystem services in the Brazilian Savanna-MapES. Ecol. Indic. 2017, 82, 513-525. [CrossRef]

78. Pyne, S.J. World Fire: The Culture of Fire on Earth; University of Washington Press: Washington, DC, USA, 1997.

79. Warming, E.; Ferri, M.G. Lagoa Santa e a Vegetação de cerrados brasileiros; Editora da Universidade de São Paulo: São Paulo, Brazil, 1973.

80. INPE. Instituto Nacional de Pesquisas Espaciais. Programa Queimadas. Available online: http://www.inpe. br/queimadas/portal (accessed on 12 February 2019).

81. Veenendaal, E.M.; Torello-Raventos, M.; Miranda,H.S.; Sato, N.M.; Oliveras, I.; van Langevelde, F.; Asner, G.P.; Lloyd, J. On the relationship between fire regime and vegetation structure in the tropics. New Phytol. 2018, 218, 153-166. [CrossRef] [PubMed]

82. Klink, C.A.; Solbrig, O.T. Efeito do fogo na biodiversidade de plantas do Cerrado. In Biodivesidad y Funcionamento de Pastizales y Sabanas em America Latina; Cyted y Cielat: Mérida, Venezuela, 1996; pp. 231-234.

83. Coutinho, L.M. O bioma do Cerrado. In Eugen Warming e o Cerrado Brasileiro: Um Século Depois; UNESP: São Paulo, Brazil, 2002.

84. IBGE. Manual Técnico da Vegetação Brasileira; $2^{a}$ Edição; Instituto Brasileiro de Geografia e Estatística-IBGE: Rio de Janeiro, Brazil, 2011; Volume 39, ISBN 9788524042225.

85. Uhl, C.; Kauffman, J.B. Deforestation, Fire Susceptibility, and Potential Tree Responses to Fire in the Eastern Amazon. Ecol. Soc. Am. 1990, 71, 437-449. [CrossRef]

86. Alencar, A.; Nepstad, D.; Del Carmen Vera Diaz, M. Forest understory fire in the Brazilian Amazon in ENSO and non-ENSO years: Area burned and committed carbon emissions. Earth Interact. 2006, 10. [CrossRef]

87. Morton, D.C.; Le Page, Y.; DeFries, R.; Collatz, G.J.; Hurtt, G.C. Understorey fire frequency and the fate of burned forests in southern Amazonia. Philos. Trans. R. Soc. B Biol. Sci. 2013, 368. [CrossRef]

88. Tyukavina, A.; Hansen, M.C.; Potapov, P.V.; Stehman, S.V.; Smith-Rodriguez, K.; Okpa, C.; Aguilar, R. Types and rates of forest disturbance in Brazilian Legal Amazon, 2000-2013. Sci. Adv. 2017, 3, 1-15. [CrossRef]

89. Van Der Werf, G.R.; Randerson, J.T.; Giglio, L.; Van Leeuwen, T.T.; Chen, Y.; Rogers, B.M.; Mu, M.; Van Marle, M.J.E.; Morton, D.C.; Collatz, G.J.; et al. Global fire emissions estimates during 1997-2016. Earth Syst. Sci. Data 2017, 9, 697-720. [CrossRef]

90. Balch, J.R.K.; Nepstad, D.C.; Brando, P.M.; Curran, L.M.; Portela, O.; de Carvalho, O.; Lefebvre, P. Negative fire feedback in a transitional forest of southeastern Amazonia. Glob. Chang. Biol. 2008, 14, 2276-2287. [CrossRef]

91. Chen, Y.; Morton, D.C.; Jin, Y.; Gollatz, G.J.; Kasibhatla, P.S.; Van Der Werf, G.R.; Defries, R.S.; Randerson, J.T. Long-term trends and interannual variability of forest, savanna and agricultural fires in South America. Carbon Manag. 2013, 4, 617-638. [CrossRef]

92. Rosan, T.M.; Aragão, L.E.O.C.; Oliveras, I.; Phillips, O.L.; Malhi, Y.; Gloor, E.; Wagner, F.H. Extensive 21st-Century Woody Encroachment in South America's Savanna. Geophys. Res. Lett. 2019, 46, 6594-6603. [CrossRef]

93. Montibeller, B.; Kmoch, A.; Virro, H.; Mander, Ü.; Uuemaa, E. Increasing fragmentation of forest cover in Brazil's Legal Amazon from 2001 to 2017. Sci. Rep. 2020, 10, 1-13. [CrossRef] [PubMed]

94. Nepstad, D.C.; Veríssimo, A.; Alencar, A.; Nobre, C.; Lima, E.; Lefebvre, P.; Schlesinger, P.; Potter, C.; Moutinho, P.; Mendoza, E.; et al. Large-scale impoverishment of amazonian forests by logging and fire. Nature 1999, 398, 505-508. [CrossRef]

95. Miranda, H.S.; Neto, W.N.; Castro-Neves, B.M. Caracterização das queimadas de Cerrado. In Efeitos do Regime de Fogo Sobre a Estrutura de Comunidades de Cerrado: Projeto Fogo; IBAMA: Brasília/DF, Brazil, 2010; pp. 23-33. 
96. Gomes, L.; Miranda, H.S.; Silvério, D.V.; Bustamante, M.M.C. Effects and behaviour of experimental fires in grasslands, savannas, and forests of the Brazilian Cerrado. For. Ecol. Manag. 2020, 458. [CrossRef]

97. Kauffman, J.B.; Cummings, D.L.; Ward, D.E. Relationships of Fire, Biomass and Nutrient Dynamics along a Vegetation Gradient in the Brazilian Cerrado. J. Ecol. 1994, 82, 519. [CrossRef]

98. Miranda, H.S.; Bustamante, M.M.C.; Miranda, A.C. The Fire Factor. In The Cerrados of Brazil: Ecology and Natural History of a Neotropical Savanna; Press C.U.: New York, NY, USA, 2002; pp. 51-68.

99. Miranda, H.S.; Sato, M.N.; Neto, W.N.; Aires, F.S. Fires in the Cerrado. In Tropical Fire ecology: Climate Change, Land Use and Ecosystem Dynamics; SPP Pumps Ltd.: Reading, UK, 2009; pp. 427-450.

100. MCTI. Third National Communication of Brazil to the United Nations Framework Convention on Climate Change-Volume III; Ministério da Ciência, Tecnologia e Inovação: Brasília/DF, Brazil, 2016; ISBN 9788588063228.

101. Ramos-Neto, M.B.; Pivello, V.R. Lightning fires in a Brazilian Savanna National Park: Rethinking management strategies. Environ. Manag. 2000, 26, 675-684. [CrossRef] [PubMed]

102. Medeiros, M.B.; Fiedler, N.C. Incêndios florestais no Parque Nacional da Serra da Canastra: Desafios para a conservação da biodiversidade. Ciência Florest. 2003, 14, 157-168. [CrossRef]

103. França, H.; Ramos Neto, M.B.; Setzer, A. O fogo no Parque Nacional das Emas; MInistério do Meio Ambiente: Brasília/DF, Brazil, 2007; ISBN 8577380416.

104. Gorgone-Barbosa, E.; Pivello, V.R.; Rissi, M.N.; Zupo, T.; Fidelis, A. A importância da consideração de espécies invasoras no manejo integrado do fogo. Biodivers. Bras. 2016, 6, 27-40.

105. Schmidt, I.B.; Fonseca, C.B.; Ferreira, M.C.; Sato, M.N. Experiências internacionais de manejo integrado do fogo em áreas protegidas-Recomendações para implementação de manejo integrado de fogo no Cerrado. Biodivers. Bras. 2016, 6, 41-54.

106. Schmidt, I.B.; Fonseca, C.B.; Ferreira, M.C.; Sato, M.N. Implementação do Programa Piloto de Manejo Integrado do Fogo em três Unidades de Conservação do Cerrado. Biodivers. Bras. 2016, 6, 55-70.

107. Eloy, L.A.; Bilbao, B.; Mistry, J.; Schmidt, I.B. From fire suppression to fire management: Advances and resistances to changes in fire policy in the savannas of Brazil and Venezuela. Geogr. J. 2018, 1-13. [CrossRef]

108. Mistry, J.; Schmidt, I.B.; Eloy, L.; Bilbao, B. New perspectives in fire management in South American savannas: The importance of intercultural governance. Ambio 2018, 48, 172-179. [CrossRef] [PubMed]

109. Alvarado, S.T.; Fornazari, T.; Cóstola, A.; Morellato, L.P.C.; Silva, T.S.F. Drivers of fire occurrence in a mountainous Brazilian cerrado savanna: Tracking long-term fire regimes using remote sensing. Ecol. Indic. 2017, 78, 270-281. [CrossRef]

110. Pereira, A.C.; Oliveira, S.L.J.; Pereira, J.M.C.; Turkman, M.A.A. Modelling fire frequency in a Cerrado savanna protected area. PLoS ONE 2014, 9, e102380. [CrossRef] [PubMed]

111. Komissarov, B.N.; Becher, H.; Levy, P.M.; Silva, D.G.B.; Braga, M.P. Os diários de Langsdorff; Campinas: Associação Internacional de Estudos Langsdorff; Editora FIOCRUZ: Rio de Janeiro, Brazil, 1997; Volume 1, ISBN 8586515027.

112. Klein, A.L. Eugen Warming e o Cerrado Brasileiro: Um Século Depois; UNESP: São Paulo, Brazil, 2002; ISBN 8571393540.

113. Appezzato-da-Glória, B.; Cury, G.; Soares, M.K.M.; Rocha, R.; Hayashi, A.H. Underground systems of Asteraceae species from the Brazilian Cerrado. J. Torrey Bot. Soc. 2008, 135, 103-113. [CrossRef]

114. Simon, M.F.; Grether, R.; De Queiroz, L.P.; Skemae, C.; Pennington, R.T.; Hughes, C.E. Recent assembly of the Cerrado, a neotropical plant diversity hotspot, by in situ evolution of adaptations to fire. Proc. Natl. Acad. Sci. USA 2009, 106, 20359-20364. [CrossRef]

115. Simon, M.F.; Pennington, T. Evidence for adaptation to fire regimes in the tropical savannas of the Brazilian Cerrado. Int. J. Plant Sci. 2012, 173, 711-723. [CrossRef]

116. Dantas, V.L.; Pausas, J.G. Megafauna biogeography explains plant functional trait variability in the tropics. Glob. Ecol. Biogeogr. 2020, 1-11. [CrossRef]

117. Medeiros, M.B.; Miranda, H.S. Post-fire resprouting and mortality in Cerrado woody plant species over a three-year period. Edinb. J. Bot. 2008, 65, 53-68. [CrossRef]

118. Pausas, J.G.; Keeley, J.E. A burning story: The role of fire in the history of life. Bioscience 2009, 59, 593-601. [CrossRef] 
119. Mendonça, R.C.; Felfili, J.M.; Walter, B.M.T.; Silva-Júnior, M.C.; Filgueiras, T.S.; Nogueira, P.E.; Fagg, C.W. Flora vascular do bioma Cerrado: Checklist com 12.356 espécies. In Cerrado: Ecologia e Flora; Embrapa Informação e Tecnologia: Brasília/DF, Brazil, 2008; pp. 423-1279.

120. Klink, C.A.; Machado, R.B. Conservation of the Brazilian Cerrado. Megadiversidade 2005, 1, 147-155. [CrossRef]

121. Oliveira, R.C.; Welker, C.A.D.; Fieker, C.Z.; Filgueiras, T.S.; dos Sousa, M.W.S. A new species of mesosetum (Poaceae: Paspaleae: Arthropogoninae) with a winged rachis from Serra da Canastra, Minas Gerais, Brazil. Phytotaxa 2019, 404, 155-162. [CrossRef]

122. Da Espírito Santo, F.S.; Sousa, D.J.L.; Chagas, D.B.; Morais, I.L.; Ribeiro, P.L.; Rapini, A. Four New Species of Marsdenia (Apocynaceae) from the Cerrado Doma. Syst. Bot. 2018, 43, 571-578. [CrossRef]

123. Da Moreira, A.L.C.; Simão-Bianchini, R.; Cavalcanti, T.B. Two new species of Bonamia (Convolvulaceae) endemic to the Brazilian cerrado. Phytotaxa 2018, 361, 106-114. [CrossRef]

124. Souza, P.C.B.; Bove, C.P. A new species of Utricularia (Lentibulariaceae) from Chapada dos Veadeiros (Central Brazil). Syst. Bot. 2011, 36, 465-469. [CrossRef]

125. Batista, J.A.N.; Meneguzzo, T.E.C.; Salazar, G.A.; Ramalho, A.J.; De Bem Bianchetti, L. Phylogenetic placement, taxonomic revision and a new species of Nothostele (Orchidaceae), an enigmatic genus endemic to the cerrado of central Brazil. Bot. J. Linn. Soc. 2011, 165, 348-363. [CrossRef]

126. Jordão, L.S.B.; Morim, M.P.; Baumgratz, J.F.A.; Simon, M.F. A new species of Mimosa (Leguminosae) endemic to the Brazilian Cerrado. Phytotaxa 2017, 312, 237-246. [CrossRef]

127. Ratter, J.A.; Bridgewater, S.; Ribeiro, J.F. Analysis of the Floristic Composition of the Brazilian Cerrado Vegetation III: Comparison of the Woody Vegetation of 376 Areas. Edinb. J. Bot. 2003, 60, 57-109. [CrossRef]

128. Rosa, C.M.M. Recuperação Pós-fogo do Estrato Rasteiro de um Campo Sujo de Cerrado; Dissertação de Mestrado, Universidade de Brasília: Brasília, Brazil, 1990.

129. Coutinho, L.M. Fire in the Ecology of the Brazilian Cerrado. In Fire in the Tropical Biota-Ecosystem Process and Global Challenges; Ecological Studies; Springer: Berlin, Germany, 1990; pp. 82-105.

130. Silva, M.A.; Nogueira, P.E. Comportamento do Estrato Arbustivo-Herbáceo de um Cerrado Após um Incêndio Acidental na Reserva Ecológica do IBGE_Distrito Federal; Boletim do Herbário Ezechias Paulo Heringer: Brasília/DF, Brazil, 1999; Volume 4, pp. 65-79.

131. Munhoz, C.B.R.; Felfili, J.M. Phenology of the herbaceous layer in a campo sujo community in the fazenda Água limpa, Federal District, Brazil. Acta Bot. Bras. 2005, 19, 979-988. [CrossRef]

132. Andrade, S.M.A. Dinâmica do Combustível Fino e Produção Primária do Estrato Rasteiro de Áreas de Campo Sujo de Cerrado Submetidas a Diferentes Regimes de Queimas; Dissertação de Mestrado, Universidade de Brasília: Brasília, Brazil, 1998.

133. Sato, M.N.; Miranda, H.S.; Maia, J.M. O fogo e o estrato arbóreo do Cerrado: Efeitos imediatos e de longo prazo. In Efeitos do regime do fogo sobre a estrutura de comunidades de cerrado: Resultados do Projeto Fogo; IBAMA: Brasília/DF, Brazil, 2010; pp. 77-91. ISBN 9788573003055.

134. Hoffmann, W.A. Post-burn reproduction of woody plants in a neotropical savanna: The relative importance of sexual and vegetative reproduction. J. Appl. Ecol. 1998, 35, 422-433. [CrossRef]

135. Medeiros, M.B.; Miranda, H.S. Mortalidade pós-fogo em espécies lenhosas de campo sujo submetido a três queimadas prescritas anuais. Acta Bot. Bras. 2005, 19, 493-500. [CrossRef]

136. Silva, E.P.R. Efeito do Regime de Queima na Taxa de Mortalidade e Estrutura da Vegetação Lenhosa de Campo sujo de Cerrado, Dissertação de Mestrado; Universidade de Brasília: Brasília, Brazil, 1999.

137. Sato, M.N. Efeito a Longo Prazo de Queimadas Prescritas na Estrutura de Comunidade de Lenhosas da Vegetação do Cerrado Sensu Stricto; Tese de Doutorado, Universidade de Brasília: Brasília, Brazil, 2003.

138. Ramos, A.E. Efeito do Fogo bienal e Quadrenal na Estrutura Populacional e Reprodução de Quatro Espécies Vegetais do Cerrado Sensu Stricto; Tese de Doutorado, Universidade de Brasília: Brasília, Brazil, 2004.

139. Palermo, A.C.; Miranda, H.S. Efeito do fogo na produção de frutos de Qualea parviflora Mart. (Vochysiaceae) em cerrado sensu stricto. Rev. Árvore 2012, 36, 685-693. [CrossRef]

140. Gawryszewski, F.M.; Sato, M.N.; Miranda, H.S. Frequent fires alter tree architecture and impair reproduction of a common fire-tolerant savanna tree. Plant Biol. 2019, 22, 106-112. [CrossRef]

141. Moreira, A.G. Effects of fire protection on savanna structure in Central Brazil. J. Biogeogr. 2000, 27, 1021-1029. [CrossRef] 
142. Eiten, G.; Sambuichi, R.H.R. Effect of long-term periodic fire on plant diversity in a cerradão. In Anais do VIII Simpósio Sobre o Cerrado 1st International Symposium on Tropical Savannas; Nasser, Ed.; EMBRAPA-CPAC: Planaltina/DF, Brazil, 1996.

143. Durigan, G.; Ratter, J.A. The need for a consistent fire policy for Cerrado conservation. J. Appl. Ecol. 2016, 53, 11-15. [CrossRef]

144. Deus, F.F.; Oliveira, P.E. Changes in floristic composition and pollination systems in a "Cerrado" community after 20 years of fire suppression. Rev. Bras. Bot. 2016, 39, 1051-1063. [CrossRef]

145. Lenza, E.; Abadia, A.C.; Menegat, H.; Lúcio, N.W.; Maracahipes-Santos, L.; Mews, H.A.; dos Santos, J.O.; Martins, J. Does fire determine distinct floristic composition of two cerrado savanna communities on different substrates? Acta Bot. Bras. 2017, 31, 250-259. [CrossRef]

146. Quesada, C.A.; Miranda, A.C.; Hodnett, M.G.; Santos, A.J.B.; Miranda, H.S.; Breyer, L.M. Seasonal and depth variation of soil moisture in a burned open savanna (campo sujo) in central Brazil. Ecol. Appl. 2004, 14, $33-41$. [CrossRef]

147. Quesada, C.A.; Hodnett, M.G.; Breyer, L.M.; Santos, A.J.B.; Andrade, S.; Miranda, H.S.; Miranda, A.C.; Lloyd, J. Seasonal variations in soil water in two woodland savannas of central Brazil with different fire history. Tree Physiol. 2008, 28, 405-415. [CrossRef]

148. Breyer, L.M. Fluxos de Energia, Carbono e Água em Áreas de Cerrado Sensu Stricto Submetidas a Diferentes Regimes de Queima; Tese de Doutorado, Universidade de Brasília: Brasília, Brazil, 2001.

149. Miranda, H.S.; Rocha-Silva, E.P.; Miranda, A.C. Comportamento do fogo em queimadas de campo sujo. In Impactos de Queimadas em Áreas de Cerrado e Restinga; ECL-UnB: Brasília/DF, Brazil, 1996; pp. 1-10.

150. Maia, J.M.F. Balanço de Energia e Fluxo de Carbono em Uma Área de Cerrado que Sofreu Queima Acidental; Tese de Doutorado, Universidade de Brasília: Brasília, Brazil, 2003.

151. Staver, A.C.; Archibald, S.; Levin, S.A. The global extent and determinants of savanna and forest as alternative biome states. Science 2011, 334, 230-232. [CrossRef] [PubMed]

152. Staver, A.C.; Archibald, S.; Levin, S. Tree cover in sub-Saharan Africa: Rainfall and fire constrain forest and savanna as alternative stable states. Ecology 2011, 92, 1063-1072. [CrossRef] [PubMed]

153. Hoffmann, W.A.; Geiger, E.L.; Gotsch, S.G.; Rossatto, D.R.; Silva, L.C.R.; Lau, O.L.; Haridasan, M.; Franco, A.C. Ecological thresholds at the savanna-forest boundary: How plant traits, resources and fire govern the distribution of tropical biomes. Ecol. Lett. 2012, 15, 759-768. [CrossRef] [PubMed]

154. Berlinck, C.N.; Batista, E.K.L. Good fire, bad fire: It depends on who burns. Flora 2020, 268, 151610. [CrossRef]

155. Durigan, G. Zero-fire: Not possible nor desirable in the Cerrado of Brazil. Flora 2020, 268, 151612. [CrossRef]

156. Fidelis, A. Is fire always the "bad guy"? Flora 2020, 268, 151611. [CrossRef]

157. Schmidt, I.B.; Eloy, L. Fire regime in the Brazilian Savanna: Recent changes, policy and management. Flora 2020, 268, 151613. [CrossRef]

158. Garrett, R.D.; Lambin, E.F.; Naylor, R.L. Land institutions and supply chain configurations as determinants of soybean planted area and yields in Brazil. Land Use Policy 2012, 31, 385-396. [CrossRef]

159. Goedert, W.J. Estratégias de manejo das savannas. In Las Sabanas Americanas: Aspectos de su Biogeografia, Ecologia y Utilizacion; Guanara, A.C.V., Ed.; Fondo Editorial Acta Científica Venezolana: Caracas, Venezuela, 1990; pp. 191-218. ISBN 84-8272-131-3.

160. Faleiro, F.G.; Andrade, S.R.M.; Reis Jíunior, F.B. Biotecnologia: Estado da arte e Aplicações na Agropecuária; Embrapa Cerrados: Planaltina/DF, Brazil, 2011; ISBN 9788570750594.

161. Bragança, A.; Assunção, J. Insights: Pathways for Sustainable Agricultural Production in Brazil-Necessary Investments and Potential Gains of Increasing Efficiency; Núcleo De Avaliação De Políticas Climáricas Puc-Rio: Rio de Janeiro, Brazil, 2019; 6p.

162. Brasil. Ministério do Meio Ambiente. Mapeamento do uso e cobertura do Cerrado: Projeto TerraClass Cerrado 2013; Ministério do Meio Ambiente (MMA): Brasília/DF, Brazil, 2015; p. 67.

163. Brasil. Plano de Ação para Prevenção e Controle do Desmatamento e das Queimadas no Cerrado (PPCerrado) e Plano de Ação para Prevenção e Controle do Desmatamento na Amazônia Legal (PPCDAm); MMA, Ed.; Ministério do Meio Ambiente, Secretaria de Mudança do Clima e Florestas, Departamento de Florestas e Combate ao Desmatamento: Brasília/DF, Brazil, 2018; ISBN 9788577382934. 
164. Dickie, A.; Magno, I.; Giampietro, J.; Dolginow, A. Challenges and Opportunities for Conservation, Agricultural Production, and Social Inclusion in the Cerrado Biome. CEA Consulting 2016, 54p. Available online: http://www.climateandlandusealliance.org/wp-content/uploads/2016/09/Cerrado-biome-apppendix_ water-and-climate.pdf (accessed on 4 December 2020).

165. European Comission. A Farm to Fork Strategy for a Fair, Healthy and Environmentally-Friendly Food System; European Comission: Brussels, Belgium, 2020.

166. McKinsey Global Institute. Case Study: Will the World's Breadbaskets Become Less Reliable? Available online: $\quad$ https://www.mckinsey.com/ \{\}/media/mckinsey/business\%20functions/sustainability/our\% 20insights/will\%20the\%20worlds\%20breadbaskets\%20become\%20less\%20reliable/mgi-will-the-worldsbreadbaskets-become-less-reliable.pdf (accessed on 4 December 2020).

167. MAPA. Ministério da Agricultura, Pecuária e Abastecimento. Diretrizes para o Desenvolvimento Sustentável da Agropecuária Brasileira. Available online: www.agricultura.gov.br (accessed on 12 July 2020).

168. Klink, C.A. Tropical Savannas and Conciliating Production with Conservation Strategies: The Case of Brazil. In Life on Land, Encyclopedia of the UN Sustainable Development Goals; Springer Nature Switzerland: Cham, Switzerland, 2020; 9p, ISBN 9783319710655.

169. Sparovek, G.; Antoniazzi, L.B.; Barretto, A.; Barros, A.C.; Benevides, M.; Berndes, G.; Braga, E.P.; Calmon, M.; Groke, P.H.; Marques, F.N.A.; et al. Sustainable bioproducts in Brazil: Disputes and agreements on a common ground agenda for agriculture and nature protection Gerd. Biofuels Biopro. Biorefining 2016, 10, $204-221$. [CrossRef]

170. Gandour, C.; Assunção, J. Policy Brief: Brazil Knows What to Do to Fight Deforestation in the Amazon: Monitoring and Law Enforcement Work Must Be Strengthened; Climate Policy Inntiative PUC-Rio: Rio de Janeiro, Brazil, $2019 ; 8 \mathrm{p}$

171. Assunção, J.; Souza, P.; Pietracci, B. Insights: Sugarcane's Role in Fueling the Economy; Núcleo De Avaliação De Políticas Climáricas Puc-Rio: Rio de Janeiro, Brazil, 2016; 6p.

Publisher's Note: MDPI stays neutral with regard to jurisdictional claims in published maps and institutional affiliations.

(C) 2020 by the authors. Licensee MDPI, Basel, Switzerland. This article is an open access article distributed under the terms and conditions of the Creative Commons Attribution (CC BY) license (http://creativecommons.org/licenses/by/4.0/). 